\title{
Stratigraphy and Facies Analysis of the Govanda Formation from Western Zagros, Kurdistan Region, Northeastern Iraq
}

\author{
Kamal H. Karim \\ Department of Geology \\ College of Science \\ University of Sulaimani
}

\section{Polla A. Khanaqa}

Kurdistan Institution

for Strategic Studies

and Scientific Research

Iraq

\author{
Irfan M. Yara \\ Department of Geology \\ College of Science \\ University of Sulaimani
}

Khalid M. Sharbazheri

Kurdistan Institution for

Strategic Studies and

Scientific Research

Iraq

\author{
Soran O. Kharajiany \\ Department of Geology \\ College of Science \\ University of Sulaimani
}

Mushir M. Baziany

Department of Geology

College of Science

University of Sulaimani
Yousif O. Mohammad

Department of Geology

College of Science

University of Sulaimani
Sherzad T. Mohammed

Department of Geology

College of Science

University of Sulaimani

(Received 18/2/2018 , Accepted 3/10/2018)

\begin{abstract}
A part of the Govanda Formation is studied in five outcrops from northeastern Iraq near the Iraqi-Iranian borders. It consists of polygenic conglomerates, detrital limestones (conglomeratic limestone), and highly fossiliferous limestones of reeffore-reef facies with occasional interbedding of terrigenous sediments. Tectonically, the formation is important for its location in the very active Sanandij-Sirjan (Suture) Zone and for its deposition in Middle Miocene, which was assigned previously as an age of continental-continental colliding of Zagros Fold-Thrust belt. Additionally, it is overlaying different rocks units of pre-Miocene, especially resting on the Qulqula Radiolarian Formation in an angular unconformity relationship. The high-energy and tectonically active shallow and normal- marine environment is inferred from many facies such as coral framestone, pelecypod floatstone facies, coral and lithoclast rudstone, coral bufflestone, stromatolite bindstone, foraminifera and red algal bioclastic packstone-wackstone, reworked foraminiferal-lithoclast grainstone-
\end{abstract}


packstone, lithoclast grainstone and terrigenous lime sandstone. The environment of the formation was high energy, shallow and normal- marine sea, which consists of fore-reef, reef and back-reef. The tectonic and paleogeographic relations of the formation are discussed in terms of facies and boundary condition. It is confirmed that the Sanandij-Sirjan Zone was subjected to an extension not compression (continentalcontinental colliding), as cited in some studies. The richness of the basin and fauna indicates that it was connected to Indian Ocean and Mediterranean Sea.

Keywords: Govanda Formation, Angular unconformity, Sanandij-Sirjan Zone, Miocene facies analysis.

\begin{tabular}{|c|c|c|}
\hline \multicolumn{3}{|c|}{ شمال شرق العراق } \\
\hline سوران عثمان خراجياني & عرفان موسى يارا & كمال حاجي كريم \\
\hline قسم الجبيولوجي & قسم الجبيولوجي & قسم الجيولوجي \\
\hline كلية العلوم & كلية العلوم & كلية العلوم \\
\hline جامعة السليمانية & جامعة السلبيانية & جامعة السلبيانية \\
\hline موشير مصطفى بازياني & خاليا محمود شاريازيرى & بولا ازاد خانقاه \\
\hline قسم الجيولوجي & مؤسسة كوردستان للاراسات & مؤسسة كوردستان لللدراسات \\
\hline كلية العلوم & الاستراتيجية والبحث العلمي & الاستراتيجية والبحث العلمي \\
\hline جامعة السلبيانية & العراق & العراق \\
\hline ففيق محمد & شيرزاد & يوسف \\
\hline بوجي & 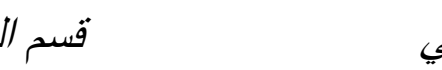 & 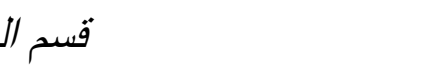 \\
\hline & & كلية | - كلية \\
\hline 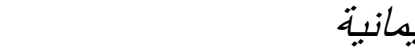 & جامعة & جامعة || \\
\hline
\end{tabular}

الملخص

درست جزء من تكوين كوفندا في خمسة مكاشف من شمال شرق العراق بالقرب من الحدود العراقية

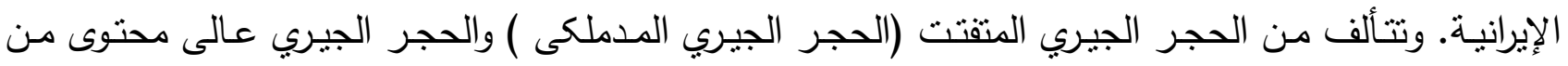


المتحجرات الراجعة الى الثعاب المرجانية و مقدمتها ، والمدملكات المتعددة الاصل مـع التداخلات العرضية

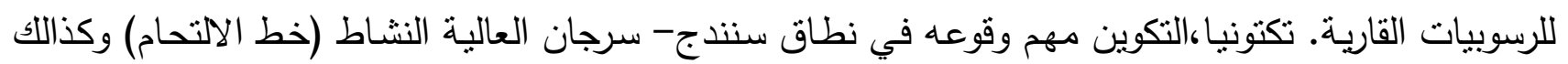
لترسّبه في المايوسين الأوسط، والذي اعتبرت سـابقًا كعمر اصطدام قـاري - قـاري لحزام الطيات و الفوالق الانزلاقية. بالإضافة إلى ذلك، فإنه يقع فوق وحدات الصخور المختلفة ذو عمر ما قبل الميوسين، وخاصة يقع فوق تكوين قولقولة راديولارينية في علاقة عدم النوافق الزاوي. استتنج الطاقة العالية وتكتونية النشطة للبيئة

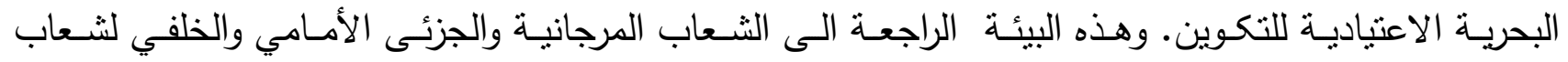

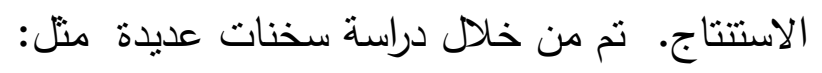

coral framestone, pelecypod floatstone, coral and lithoclast rudstone, coral bufflestone, stromatolite bindstone, foraminifera and red algal bioclastic packstonewackstone, reworked foraminiferal-lithoclast grainstone-packstone, lithoclast grainstone and terrigenous lime sandstone facies

ونم مناقتنة العلاقات التكتونية والجغرافية القديمة للتكوين من خلال السخنات وعلاقات الحدودية. أكدت أن الجزء المدروس من منطقة نطاق سنندج - سرجان خضع للتمديد وليس الانضغاط (الاصطدام القاريالقاري)، كما ورد في بعض الدراسات السابقة. غنى الحوض بالحيوانات البحرية الاعتيادية يشير إلى أنه حوضه كان متصلا بالمحيط الهندي والبحر الأبيض المتوسط. الكلمات الادالة: تكوين كَفثدا، عدم التوافق الزاوى، نطاق سنندج سرجان، تحليل سحنات، مايوسين.

\section{INTRUDUCTION}

The Govanda Formation represents the deposits of early Middle Miocene and has the thickness up to $150 \mathrm{~m}$ (Jassim and Goff, 2006). It was first described, according to Bellen et al. (1959) by Dunnington, Al-Naqib and Morton in 1957. In Iran, it is equivalent to the Asmari Formation and its type localityin Iraq lies on the northwestern slopes of the Govanda Plateau in the Imbricated Zone of northeastern Iraq at latitude $37^{\circ} 07^{\prime} 58^{\prime \prime} \mathrm{N}$ and longitude $44^{\circ} 12^{\prime} 53 " \mathrm{E}$ in Erbil Governorate. According to Bellen et al., (1959), the lithology of the type section, from top to bottom is as follows: the lowermost $6 \mathrm{~m}$ is composed of a polygenic basal conglomerate and passing upwards into conglomerates with pebbly sandstones and siltstones. These terrigenous clastics are overlained by roughly $20 \mathrm{~m}$ of silty and sandy detrital limestones with abundant derived- Cretaceous fossils. The overlyjng 80-90m, i.e. the bulk of the formation, is made up of limestones of reef-fore reef facies.

The previous studies of the Govanda Formation indicate to shallow marine reeffore-reef environment, strongly affected by the supply of the nearby rising land, as 
testified by the presence of clastics not only at the bottom, as in the type locality, but sometimes intercalating with the limestones too (Buday, 1980). He added that its lower contact is unconformable and the formation had transgressed on the Red Bed Series and its upper contact is not visible. In Shalair Valley, the thickness of the formation is about $100 \mathrm{~m}$ and it is composed of a basal conglomerate (containing chert pebbles derived from the Qulqula Radiolarian Formation), which passed upwards and laterally into fossil rich sandy limestone and capped by thick oyster-bearing limestone (Jassim and Goff, 2006). They added that the formation is unconformably underlained by the Swais Group, Tanjero Formation and locally by the Qulqula Formation.

\section{LOCATION}

The studied area belongs to Kurdistan Region, northeastern Iraq in the Sulaimani Governorate near the Iraqi-Iranian borders (Fig.1). The sections of the formation are distributed over six different areas. The first section is located at the southwestern boundary of Shalair Valley at $25 \mathrm{~km}$ to the northwest of Penjwin town (Figs.2 and 3). The center of this section is located at latitude of $35^{\circ} 45^{-} 58.82^{=} \mathrm{N}$ and longitude $45^{\circ}$ $49^{-} 29.20^{=}$E. Its outcrop (Bahe outcrop) is the largest and has length $15 \mathrm{~km}$ and $1 \mathrm{~km}$ width, and it elongates along Gole stream from Komari (southeast) to Bahe Village (northwest) (Figs.4 and 5). The second section is located at the latitude of $35^{\circ} 40^{-}$ $32.75^{\circ} \mathrm{N}$ and longitude $45^{\circ} 52^{-} 14.01^{\circ} \mathrm{E}$, and its outcrop (Qzlja outcrop) includes the area at the north and northeast of the Qzlja Village at 10km southwest of Penjwin town. These latter two outcrops are mapped by Buday and Jassim (1987).

The third section is located between Rashan and Qzlja outcrops on the Mila Kawa peak, exactly on the western side of the paved road to Penjwin Town. On the peak there is small outcrop (Mila Kawa outcrop) of the formation having about $10 \mathrm{~m}$ thickness and lateral continuity for only about $100 \mathrm{~m}$. The forth section is located in the middle of the bottom of the Rashan (Taza De) Valley especially along the southern side of the stream that flows in the valley. The center of the section is located at the intersection of latitude and longitude $35^{\circ} 31^{-} 14.91^{\circ} \mathrm{N}$ and $45^{\circ} 59^{-}$ $54.84^{=}$E respectively. Its outcrop has thickness, length and width 10, 10000 and 200 meters respectively. The fifth section (Rashan outcrop) is located at the head of Dola Chawt near Barda Balaka Village and its outcrop (Barda Balaka outcrop) is small, which is less than one quarter of square kilometer. The outcrops are distributed over both sides of the unpaved road that pass through the village (Figs.2 and 3) and rested 
on the Qulqula Radiolarian Formation. The center of this section is located at the intersection of latitude and longitude $35^{\circ} 33^{-} 07.82^{\circ} \mathrm{N}$ and $45^{\circ} 49^{-} 35.02^{=} \mathrm{E}$ respectively.

There is another section (sixth section) at $3 \mathrm{~km}$ to the west of Chwarta town. It is found by Al-Barzinjy (2005). This outcrop is very small and has a surface area of 50 square meters and it consists of coral colony limestone; and this author attributed this to the Unit Six of the Red Bed Series, but it possibly belongs to the Govanda Formation. The center of its exposure is located at latitude and longitude of $35^{\circ} 43^{-} 26.94^{=} \mathrm{N}$ and $45^{\circ} 51^{-} 32.76^{-}$respectively (Figs.2 and 3).

\section{Tectonic setting of the studied area:}

According to Buday (1980), the studied section is tectonically located within the Thrust Zone regarding the tectonic divisions of Jassim and Goff (2006). It is located in the Qulqula-Khwakurk and Penjwin-Walash Zones as two neighboring zones of the Suture Zone. The area has the most complex geological setting in Iraq, which manifested by brecciation, thrusting, transpress deformation, igneous intrusion and metamorphism.

In the studied area, four main thrust sheets can be identified in the field. The largest is outer (lower) one, which consists of the Qulqula Radiolarian Formation sheets thrusted up on different units in different formation, such as the Tanjero, the Shiranish, the Kometan and the Balambo in addition to Jurassic rocks units.

The Qulqula Radiolarian Formation is about 1000 meters thick and consists of bedded chert, siliceous shale, marl and limestones, which are studied by Karim and Baziany (2007), Karim et al. (2009), Karim et al. (2011) and Baziany (2013). The second sheet consists of the Avroman Formation, which is thrusted on the Qulqula Radiolarian Formation. The Avroman Formation is composed of detrital and biogenic limestone of reefal facies (Karim, 2007). The third sheet consists of many smaller sheets, but the main one is Penjwin Ophiolite Complex, which is thrusted on the Merga Red Bed and the Qulqula Radiolarian Formation. The Penjwin Ophiolite Complex consists of gabbro, peridotite, dunite and small bodies of acidic rocks. The fourth sheet is composed of metamorphic phyllite, hornfels and calcsilicate marble (Karim et al. 2016). Structurally, the main folds are so deformed that cannot be identified, and only the small folds are observable.

The studied area is located within the Sanandij-Sirjan Zone, it is located between Main Zagros Thrust at southwest and Urmia-Dokhtar Magmatic Zone at the northwest 
(Moghadam and Stern, 2015; Jamshidi Badr et al., 2010). However, the definition of Stocklin (1968; in Yousefirad, 2011) and tectonic map of Ghazi and Moazzen (2015) are considered in this study.

Geomorphologically, the area is a part of high- Mountain series of Zagros belt and due to aforementioned sheets. The main (large) valleys have northwest-southeast trends, which are subsequent valleys such as Taza De, Nalparez, Ahmad Klwan, Qzlja, Shalair and Gole valleys. These valleys are surrounded by high mountains from northeast and southwest, their heights are more than 2000m above mean sea level. The mountains are Suren, Spidara, Kani Shawkat, Shawkat, Taryar Qaya, Harzala, Nizara, and Bahe. Many small subsequent and consequent valleys are of descending heights from the high mountains. These valleys have emepheral streams and joining the large ones.

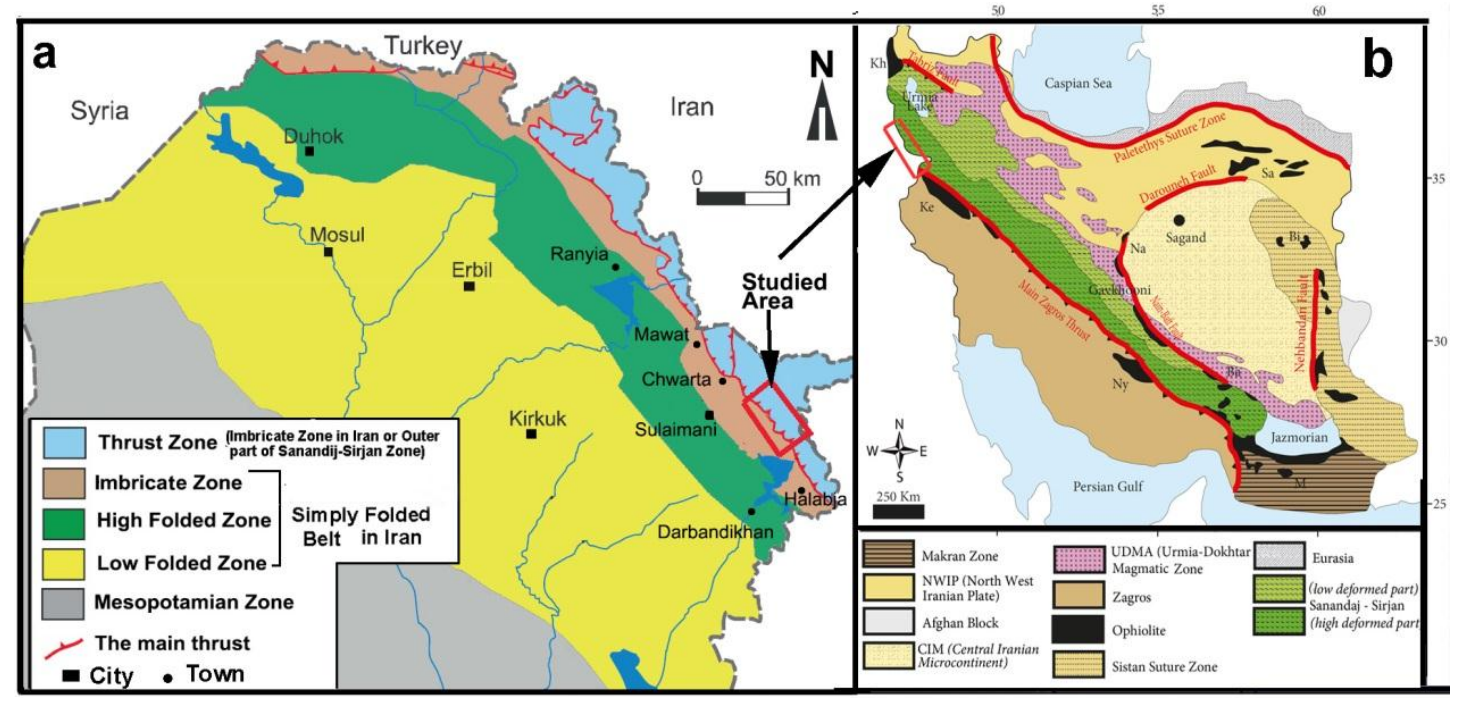

Fig. 1 a): Tectonic Subdivisions of Northern Iraq (Jassim and Goff, 2006)

Showing the Studied Area,

b): Location of the Studied area in the Zagros Fold-Thrust Belt (Modified from Ghazi and Moazzen, 2015). 


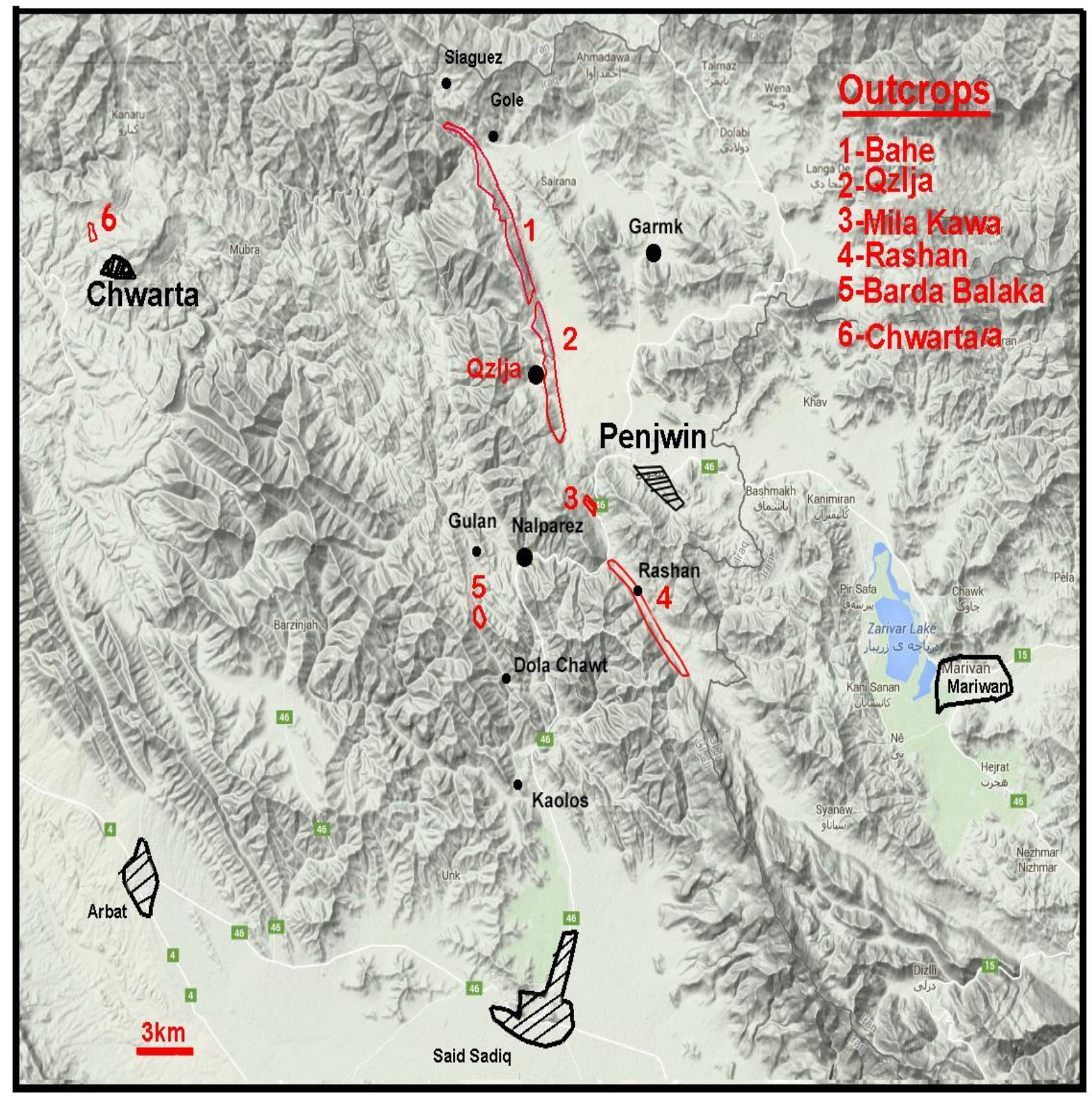

Fig. 2: Location of the Studied Outcrops on Google. 


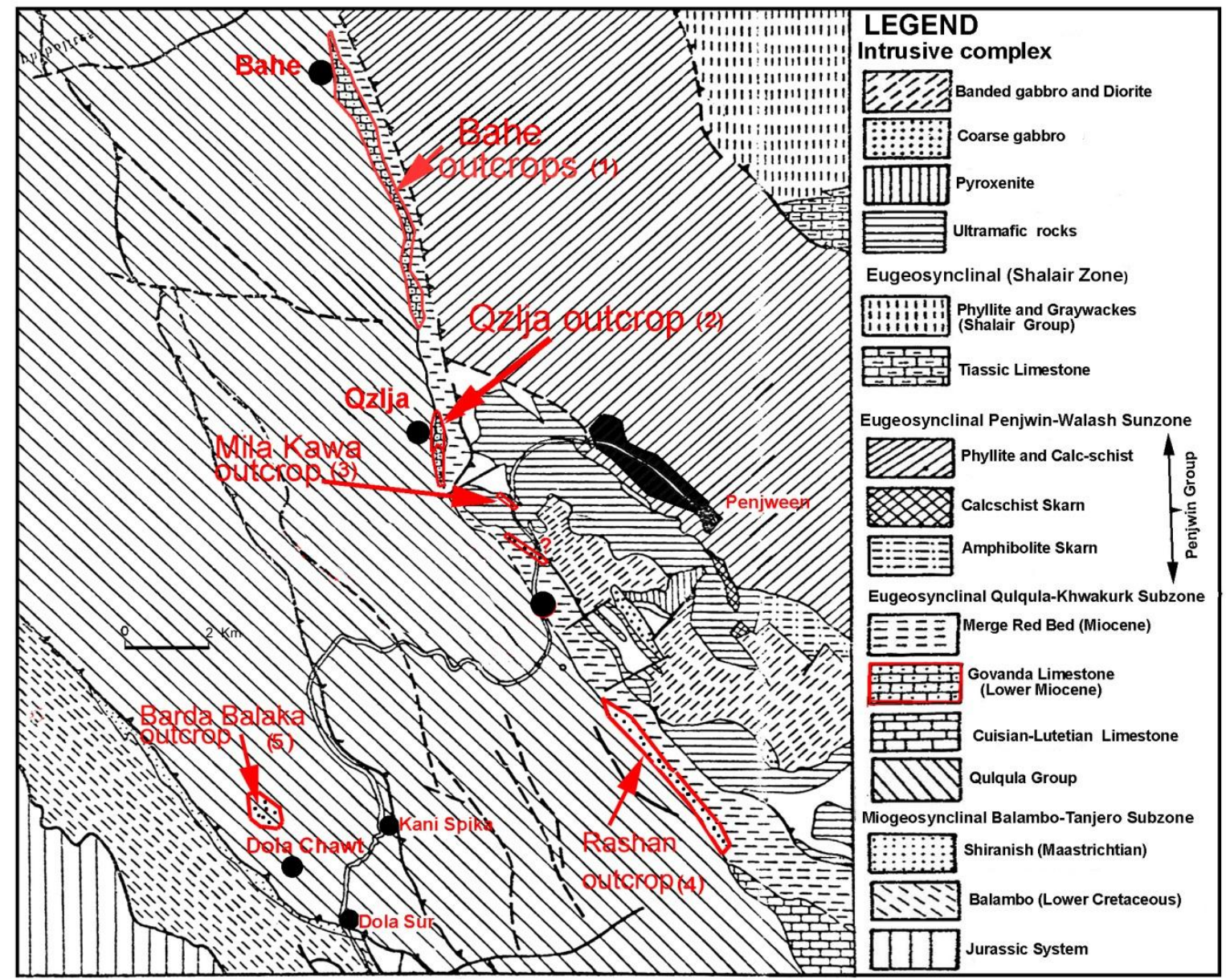

Fig. 3: Geological Map of the Studied Area (Modified from Buday and Jassim, 1987) on which the Studied Sections (outcrops) are Indicated.

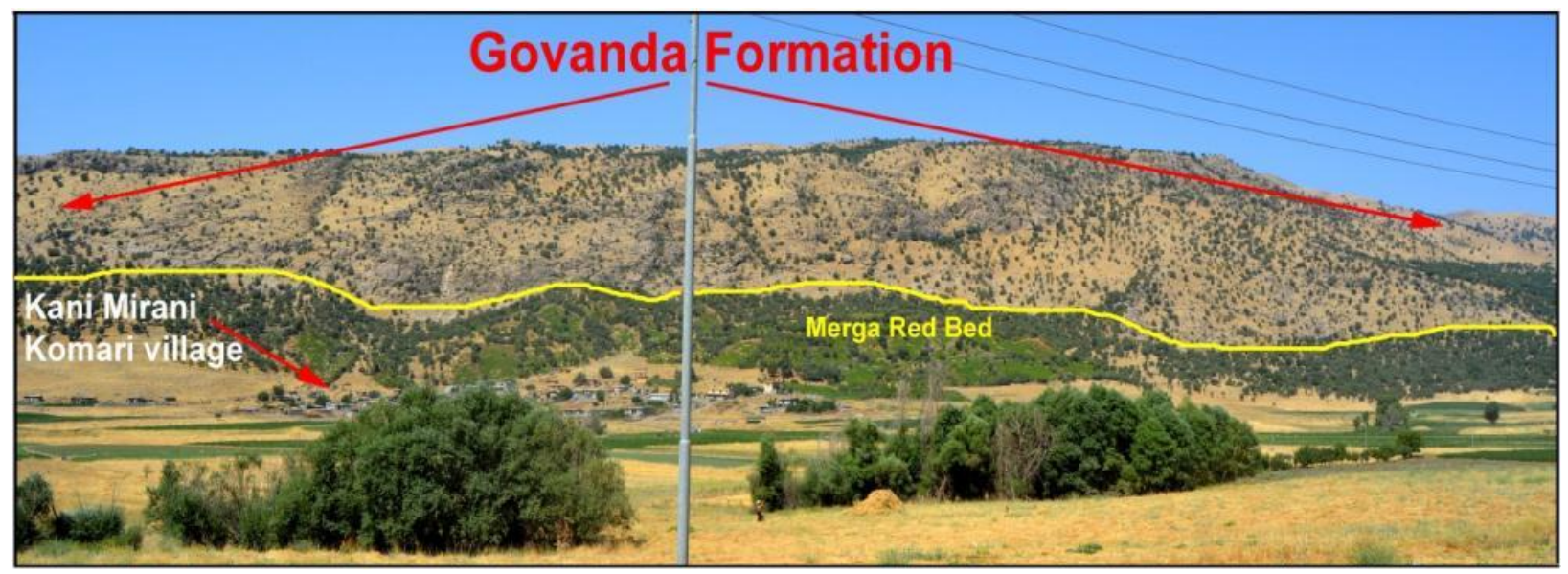

Fig. 4: An outcrop of the Govanda Formation at South and Southwest Sides of Bahe and Kani Mirani Komari, Southwestern Boundary of Shalair Valley, Penjwin Area. 


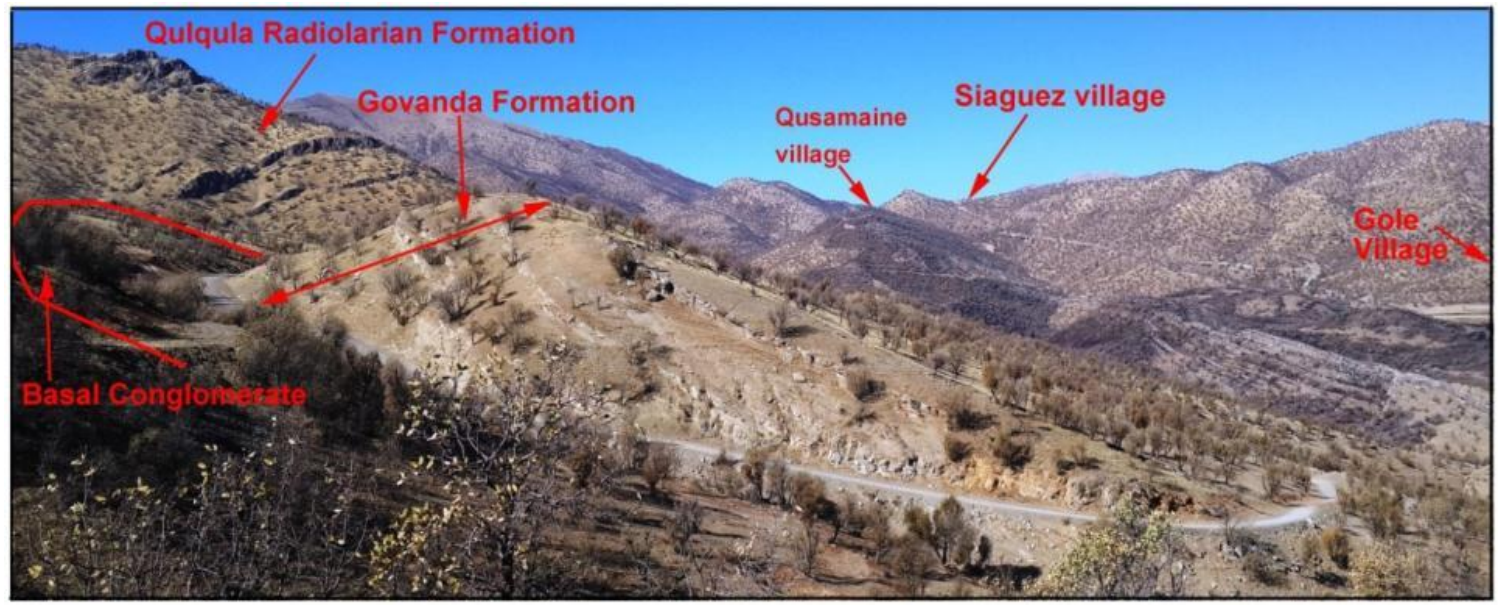

Fig. 5: An outcrop of the Govanda Formation (Section No.1) at 200m West of Bahe Village, Southwestern Boundary of Shalair Valley, Penjwin Area.

\section{Method of the study:}

This study depends on the field observations during which the upper and lower boundaries of the Govanda Formation are examined. The geographical extends are plotted on the map, and 23 samples are collected for lab study and stereoscopic microscopy for indication of allochems and orthochems. The selected samples are cut for thin section preparation to study petrography under polarizer microscope. In the thin sections and hand specimens, the facies are identified after differentiation of the rocks constituents that include faunas, lithoclasts, intraclasts, extraclsts and boiclasts. For this identification, the Dunham (1962) classification and its modification by Embry and Klovan (1971) are followed.

\section{RESULT}

\section{Geological boundaries of the formations}

\section{1- The lower boundary}

The lower contact of the Govanda Formation is exposed in many areas that are rested on different lithologic units. The type area, in Erbil Governorate, it is unconformably rested on the Kirkuk Group Formation and Tanjero Formation (Bellen et al., 1959 and Buday, 1980); and according to Al-Hietee (2012), it represents transgressive facies that is rested on the previous units. In the northwestern part of the studied area in Bahe and Qzlja outcrops (Figs.2, 3, 4 and 5), it 
unconformably overlies the Qulqula Radiolarian Formation in an angular relationship near Gole, Bahe and Qzlja Villages. The angular unconformity can be seen clearly from intensive folding of the beds of the Qulqula Radiolarian Formation below the Govanda Formation (Fig.6a). In this area, there is about $1.5 \mathrm{~m}$ of polygenetic basal conglomerates between the two formations and it consists of gravel conglomerates with red- clayey sandstone matrix or cemented by calcite (Fig.6b). In some locations, it shows intensive brecciation especially on the northern bank of the Gole stream. The same angular relationship is true for Barda Balka outcrop near Razla Village, which is rested on the Qulqula Radiolarian Formation with highly shearing, and brecciation that are possibly tectonic. The lower boundary in southeastern part of the studied area (Rashan outcrops) is rested on the sandstone of the Merga Red Bed that may be tectonic; the Merga Red Bed is possibly of late Miocene age (Buda, 1980).

\section{2- The Upper Boundary}

According to Bellen et al. (1959) and Buday (1980), the upper boundary is erosional in most places while the formation is overlained by the Merga Red Bed in some places. In the studied area, it seems that the so-called "Merga Red Bed" in Penjwin area is located below the Govanda Formation. There is a small outcrop of the formation between Rashan and Qzlja outcrops, exactly on the Milakawa peak and on the western side of the paved road. This outcrop is intensively brecciated and it consists of a mixture of detrital and nummulitic limestones with sandstone and calcareous shale (Fig.7). It is located between ophiolite (Penjwin ophiolite by Jassim and Goff, 2006) at the top, and the Merga Red Bed at the base. In this locality, both boundaries are tectonics. This outcrop contains nummulite of the Eocene age that is probably reworked. A small part of Bahe outcrop, at $800 \mathrm{~m}$ to the southwest of Gole Village, is overlain by lithified oncoidal massive limestone and travertine (Fig.8). The age of this limestone is unknown, but it may belong to Pleistocene or Sub-Recent as the dips of its strata are nearly coinciding with the local slope of the area. 


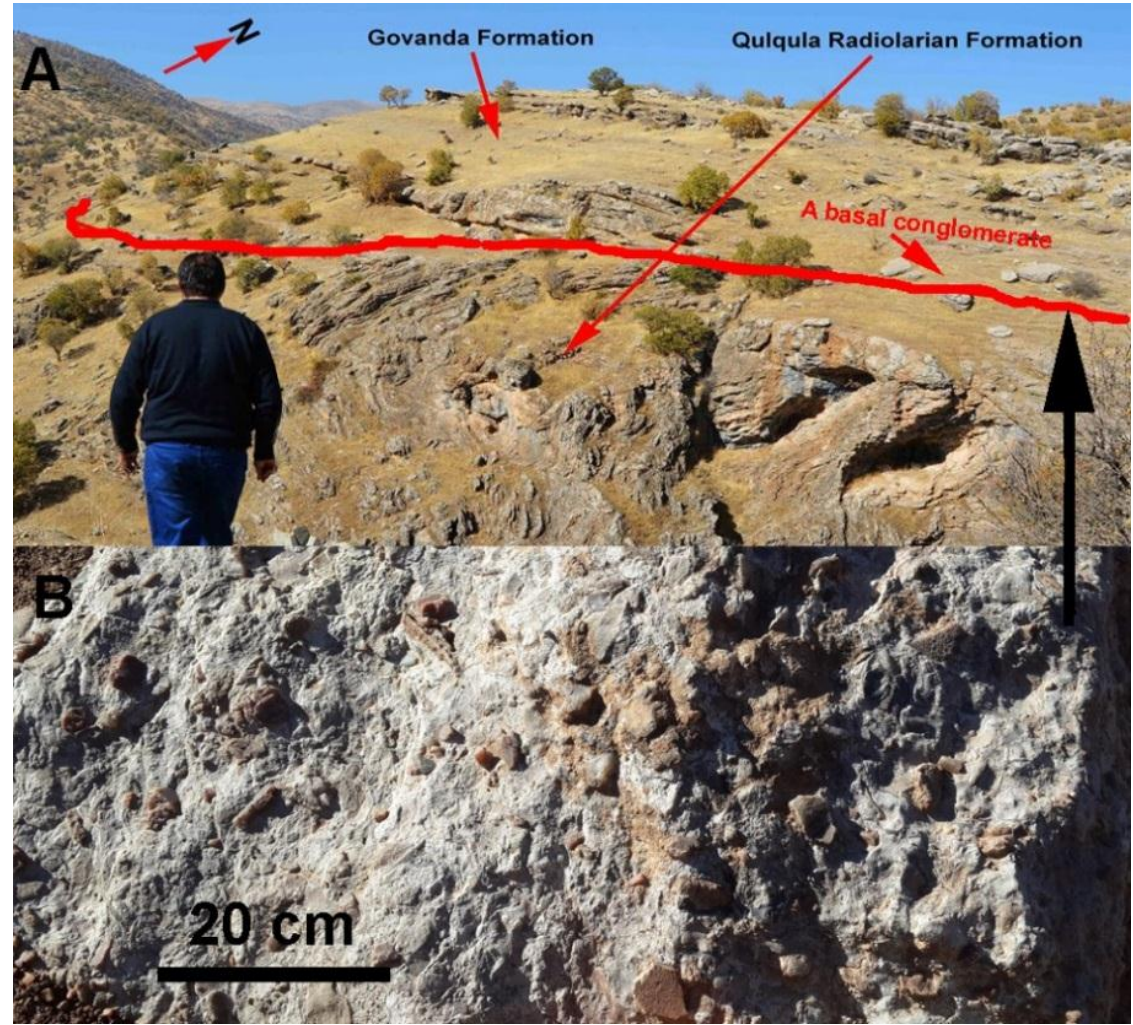

Fig. 6 A): The Govanda Formation (Middle Miocene) rested on the Qulqula Radiolarian Formation in an angular relationship (angular unconformity) at $5 \mathrm{~km}$ south of Siaguez Village in Shalair Valley directly to the north of Bahe Village. B): Basal conglomerate between the Govanda and the Qulqula Radiolarian formations near Bahe Village.

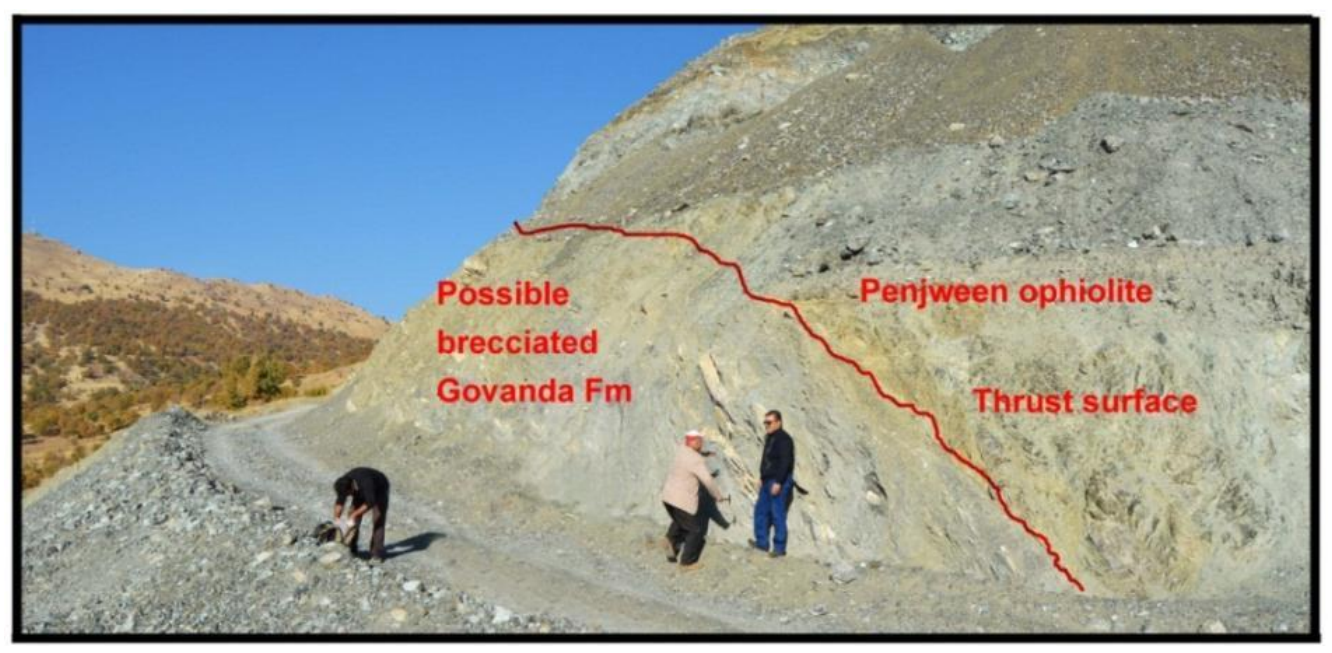

Fig. 7: Possible Govanda Formation (brecciaed) between Penjwin Ophiolite and the Merga Red Bed on the Mila Kawa peak near Kani Manga Village. 


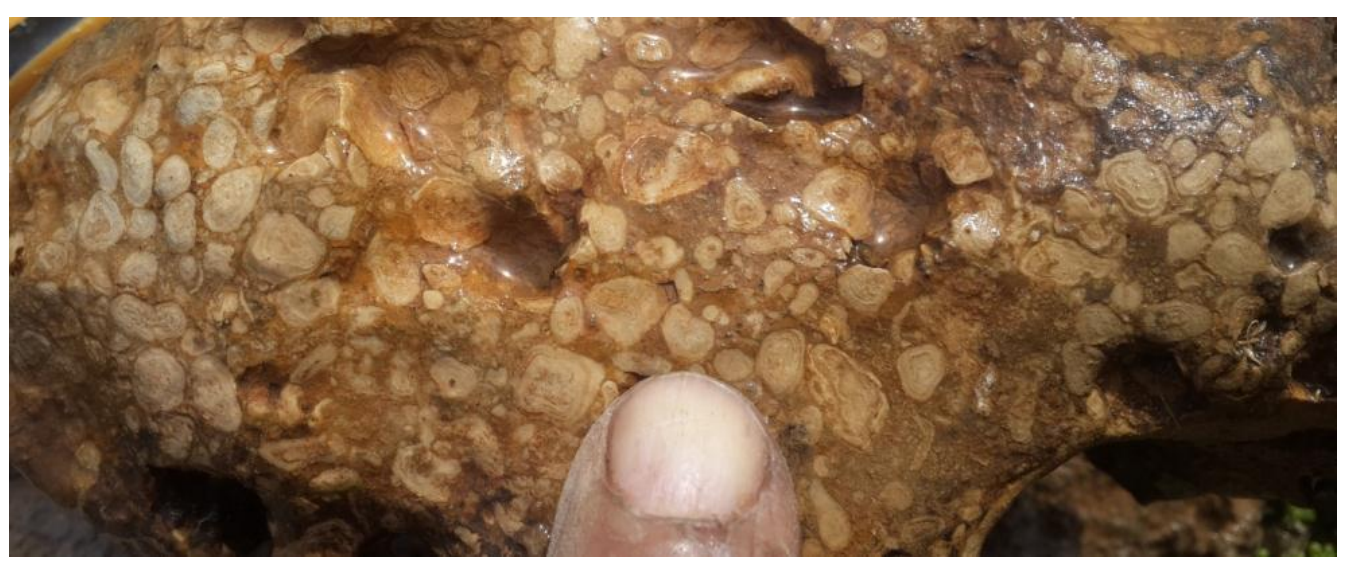

Fig. 8: Stromatolitic (oncoidal) limestone within the Govanda Formation, 200m north of Bahe Village.

\section{FACIES ANALYSIS}

Lithofacies and biofacies analyses of the Govanda Formation are difficult for interpretation due to many issues, the first issue is the presence of reworked fossils from the Cretaceous (Bellen et al, 1959) and from possible Eocene ages (Inferred from present study). The second is the complexity of its boundaries condition, which is greatly variable (geographically and chronologically), which constrained the accurate definition of the facies. The third is the intensive deformation and distortion of the allochem constituents of the facies due to its location in the Suture Zone or Sanandij-Serjan Zone; therefore, the deformation limits the accuracy of the identification. The fourth is the degree of recrystallization that diminishes the accuracy of documentation and the photos of the facies might not be clear. The fifth is that the most facies contain more or less terrigenous clasts, which restrict accurate terminology. However, many facies were found in the Govanda Formation of environmental and paleogeographic importance. These facies can be recognized in both polished slabs and thin sections. In rare cases, this facies contains whole echinoderms skeletons.

\section{1- Pelecypod floatstone Facies (F1)}

This facies is supported by a carbonate matrix that contains more than $10 \%$ grains larger than $2 \mathrm{~mm}$. The matrix of floatstone does not necessarily correspond to be only micrite, but often consists of fine-grained textures that must be described separately (Flugel, 2004). This facies is very common in the lower part Bahe section 
and it occurs rarely in the Qzlja and Barda Balaka sections (Fig.9). This facies consist of skeletons or bioclasts of pelecypods (Fig.10) with or without coral and red algae fragments (that are larger than sand size) and floated or embedded in fine matrix of sand or silt sized bioclast or lithoclasts. The thicknesses of this facies are $10-80 \mathrm{~cm}$ and have sharp base with sandy marlstone. This facies show crude lamination and alternated with sandy marlstone. In one case and in the Barda Balaka section, there is a sample contain clasts of large gastropod and other unknown fossils (Fig.11). Generally, in this outcrop and its section, the clasts are very angular and the delicate sculptures are clear, which are denoting very short distance of transportation and relatively rapid deposition. This facies may be deposited in back-reef setting.

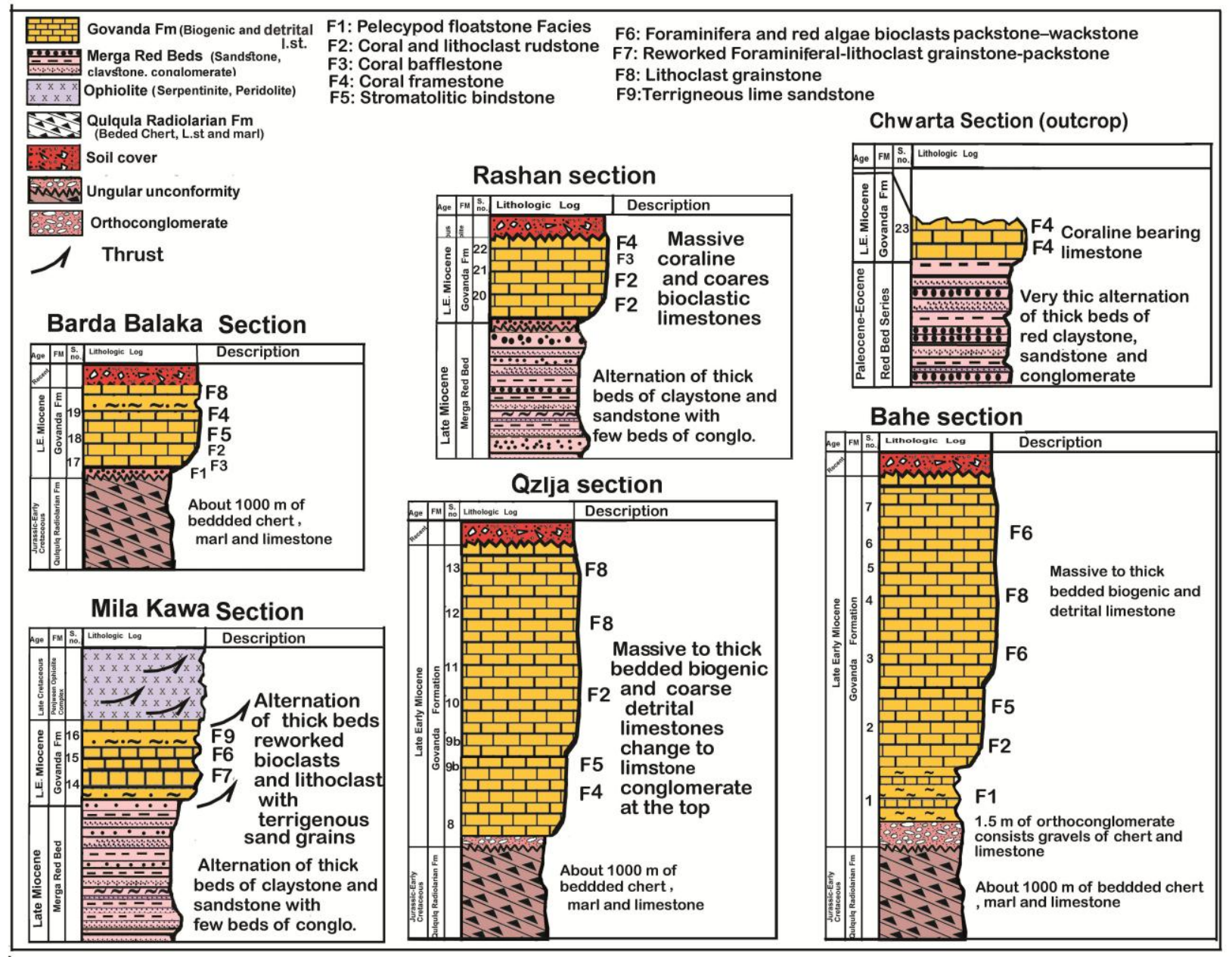

Fig. 9: Stratigraphic Column of the Studied Sections. 


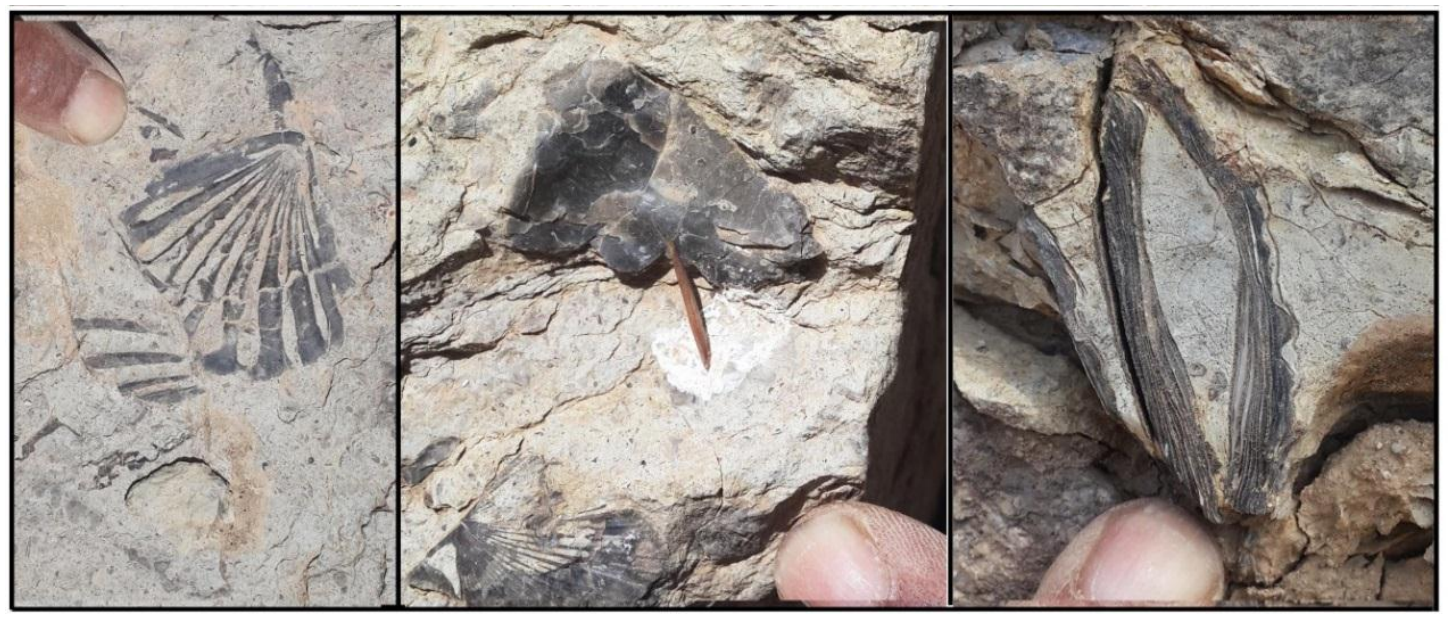

Fig. 10: Pelecypod (including oysters) Floatstone in the Lower Part of the Govanda Formation, Bahe Outcrop.

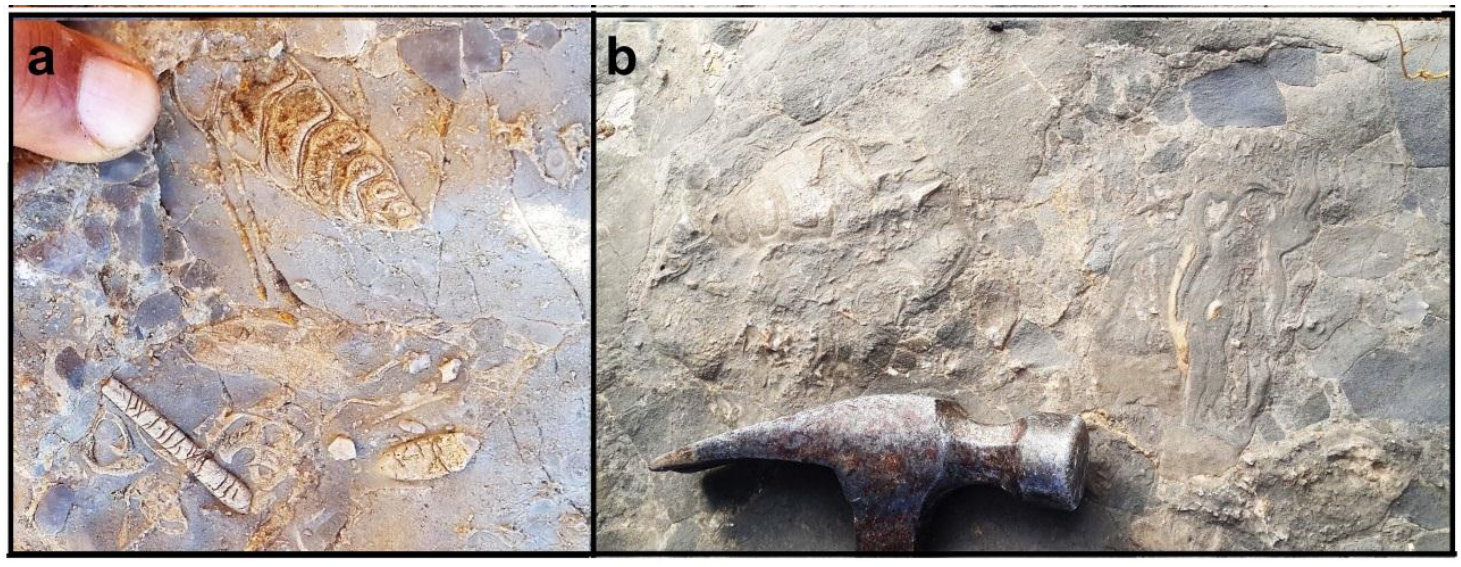

Fig. 11 a): Gastropod and lithoclast floatstone in Barda Balaka Outcrop,

b): Gastropod Lithoclast Floatstone with Patches of Stromatolite at the Left.

\section{2- Coral and lithoclast rudstone (F2)}

This facies consists of pebble-sized limestone lithoclasts and bioclasts or skeletons of coral, and it is very common in all sections. Coral bioclast rudstone is common in Rashan and Bahe sections, which consists of elongated, $2-3 \mathrm{~cm}$ long and $0.3-1 \mathrm{~cm}$ in diameter (Fig.12). The lithoclast rudstone is very common in Qzlja and Barda Balaka sections and it makes up more than 50\% of the thickness of the section (Fig.13). The lithoclast rudstones are composed of angular to sub-angular pebbles of limestone clasts of different constituents includjng coral or algae or bioclasts or lithoclasts pebbles. The lithoclasts can be called limestone conglomerates (extraformational or intraformational conglomerates) or breccia. The thickness of this 
facies is about 30m around Qzlja Village and this huge thickness cannot be formed by faulting, but it is depositional product that formed by erosion of tectonically fractured limestones in the basin or on surrounding terrestrial lands; or it may be a reef talus deposit.

This facies might be derived from reef tops and deposited in a high energy setting (forereef) due to rock-fall and various mass-flow processes.

According to Flugel (2004), rudstone is, an equivalent to packstone and grainstone, but its grains are self-supported carbonate rocks containing more than $50 \%$ grains larger than $2 \mathrm{~mm}$. This facies can be further characterized by compositional and textural criteria. Deposition of rudstone needs erosion and transportation. Flugel farther added that erosion could be triggered by shallow water settings allowing destruction by storms.

The allochems are bound by fine-grained matrix such as: sand and silt sizedcarbonate grains in addition to lime mud (matrix-supported fabric). This facies is introduced into Dunham (1962) classification by Emery and Klovan (1971), it consists of self-supporting allochems (more than $2 \mathrm{~mm}$ in diameter) that bounded by micrite (mudstone). According to Wilson (1975), rudstones is deposited in fore-reef environment; where strong waves are prevalent. Praptisih and Kamton (2014) have found this facies in the Klapanunggal Formation (Late Miocene), western Java, Indonesia, which is deposited in fore-reef environment. Melim and Scholle (1995) have found this facies in fore-reef of Capitan Reef, which is associated with packstone and wackstone.

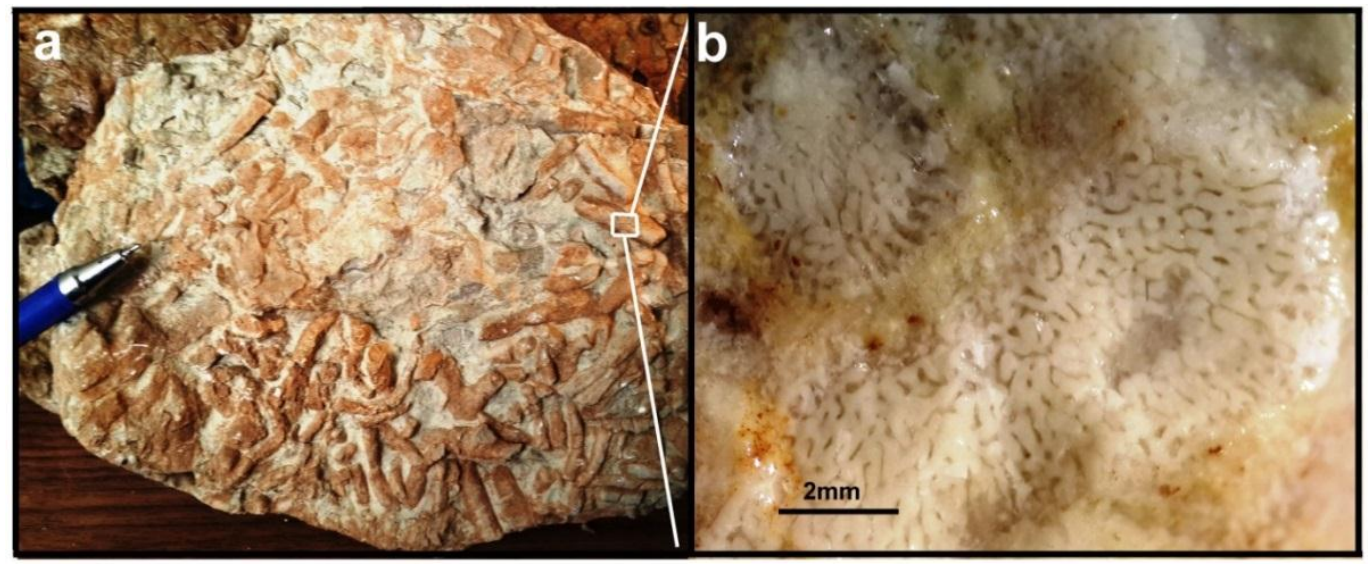

Fig. 12 a): Coral Rudstone Consisting of Broken Fragment of Scleractina Coral Colony Near Taza De Village in the Rashan Outcrop. b): Detail of the Coral under Stereoscope Microscopy. 


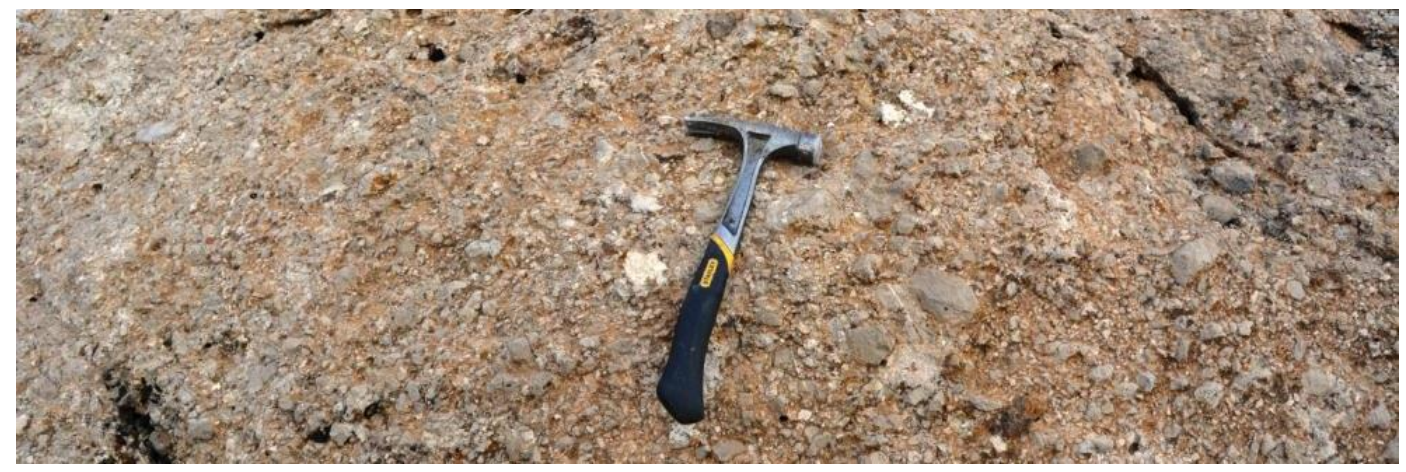

Fig. 13: Limestone Rudstone (limestone Conglomerate) in the Middle Part of the Govanda Formation at 100m North of Qzlja Village.

\section{3- Coral bafflestone (F3)}

This facies is well-expressed in the sections of Barda Balaka and Qzlja outcrops. It resembles a loose bundle of thin wood sticks of about $0.2-4 \mathrm{~cm}$ thick and more than $10 \mathrm{~cm}$ long (Fig.14). It occurs in thick and massive beds of the middle part of the section of Qzlja outcrops. The broken and re-deposited fragments of this facies have generated the coral floatstone or rudstone (Fig.12a).

In hand specimen, the red algae coated corals and other grains look like elongated oncoids (Fig.15b) but they are not oncoids due to the fact that red algae excluded from algae that formed stromatolies and oncoids (Scholle and UlmerScholle, 2006). In many cases, the corals steam and polyps are surrounded and covered by crustose red algae (Figs.15b and c), which might be resulted from the competition between algae and corals on coral reefs as discussed by McCook et al. (2001).

The spaces between the coral branches are filled with white lime mud and sandsized bioclasts. In literature, this facies is called bafflestone (Emery and Klovan, 1971), because it has dendritic shape and performs as sediment accumulator from the nutrient- bearing currents and waves by filtering and trapping sediments. Walker and James (1992) have included this facies in the colonization stage of the reef structure. The presence of corals indicates normal marine salinity (Riding and Tomas, 2006). According to Flugel (2004), the criterion for identifying the bafflestone is the presence of large number of in situ stick-shaped fossils. Pomar et al., (2005) mentioned this facies in the rocks of the Upper Cretaceous platform in the Pyrenees, 
Spain. The present study indicates that this facies is most possibly deposited in backreef environment.

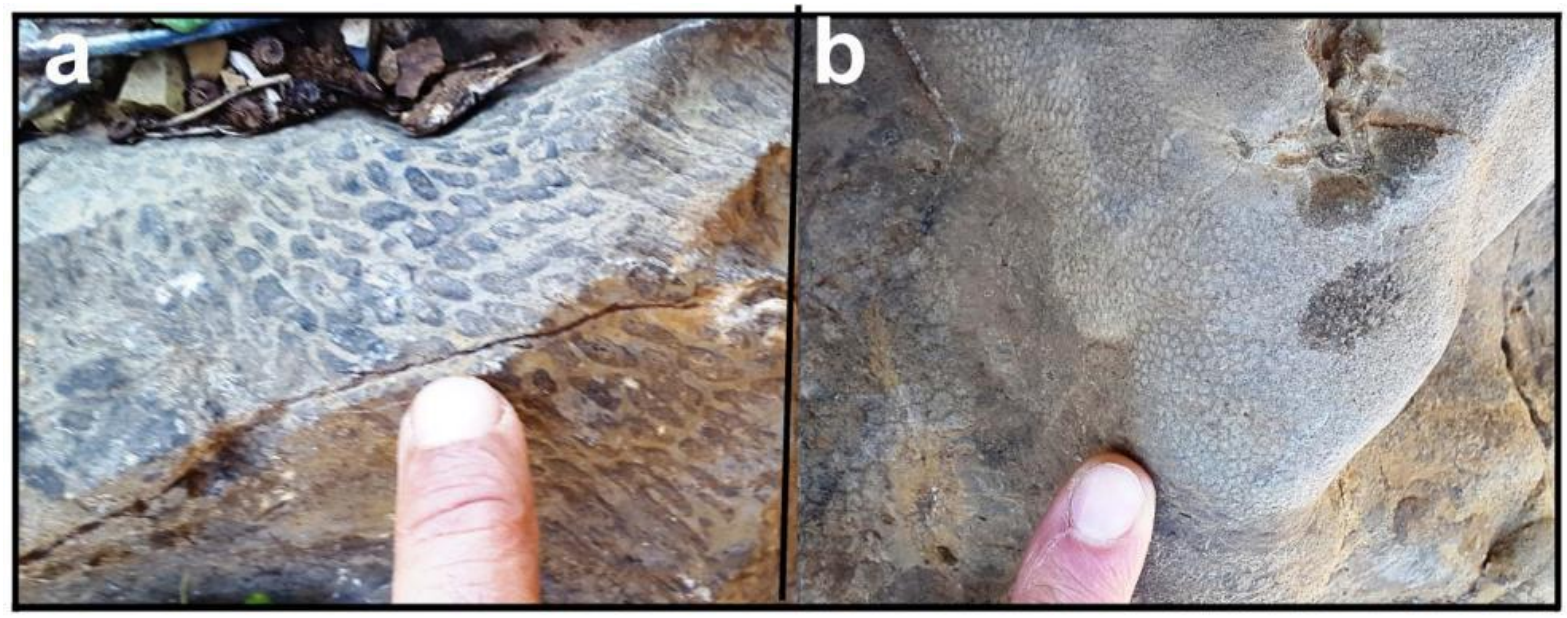

Fig. 14 a): Photo of the Coral Bafflestone of Barda Balaka Outcrop, Between the stems, Fine Lime Mud and Sand-sized Allochems are Deposited. b): Same facies of the Rashan outcrop showing vertical finger like corals streams, some are branching.

\section{4- Coral framestone (F4)}

This facies is common in Barda Balaka and Chwarta sections while it is rare in Qzlja and Bahe sections; under hand lens and binocular microscope, it consists mainly of irregular or global bodies (colonies) or patches of pentagonal coral and brain-like corals. The sizes of the colonies or patches are different, but the common one is 5- 30cm in diameter (Fig.15a, b). The spaces between patches are filled with finegrained carbonate (lime mud and fine-grained allochems). Many specimens are found to contain single large corals (mushroom corals) with a diameter of $3-7 \mathrm{~cm}$, consisting of framestone and associated with red algae (Fig.15a). The present study indicates that this facies is most possibly deposited in backreef environment. According to Flugel (2004) and Wu. et al., (2012). This facies is deposited on reef core (reef body) environment. 


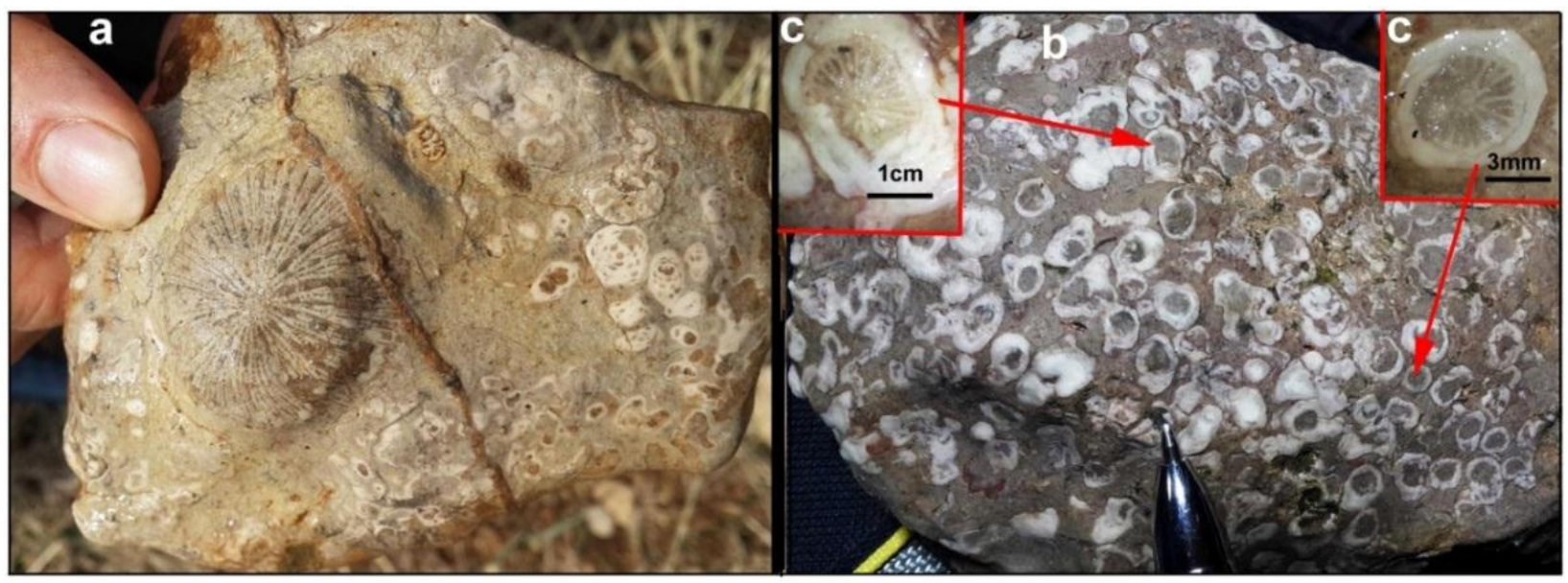

Fig. 15 a): Coral and rudstone consisting of broken fragment of scleractinian coral colony near Taza De village on the Rashan outcrop,

b): detail of the coral under stereoscope microscope.

\section{5- Stromatolitic bindstone (F5)}

Flugel (2004) cited that this facies, as a type of limestone, consists of rigid framework (skeleton) built by framework of the organisms. Embry and Klovan (1971) introduced bindstone as a part of the boundstone of Dunham (1962) to the classification of carbonate. The distribution and morphology of the skeletons should fit into an imaginary three-dimensional organic framework. Many organisms contribute to deposition of framestones as corals, coralline sponges, stromatoporoids, rudist bivalves and calcareous red algae.

In the studied sections and outcrops, this facies is not common, but it exists in all sections especially in Qzlja and Barda Balaka sections. In hand specimen, it can be seen as dense undulated and corrugated laminations that probably represent stromatolites (Fig.16a). In Qzlja section, there is a highly wavy limestone and under stereoscope microscope it shows dense reticulate texture that is made of layers of tiny pillars, which forms brick- like wall structures and are distinctive features of stromatolites (Figs.16b and 17). These limestones are stromatoporoids bindstone according to the comparison of the present sample with those published in web site (see http://www.earthsurfaceprocesses.com/3f-E-Stromatojlites Stromatoporoids.html). In the Bahe section, the stromatolitic limestone occurs too, which consists of oncoids formed by microbes (microbalite), but the age of this bed is unknown. In this context, McConnell (1975) considered this type of stromatolite as 
stratiform type and attributed its deposition to intertidal and possibly supratidal environment.

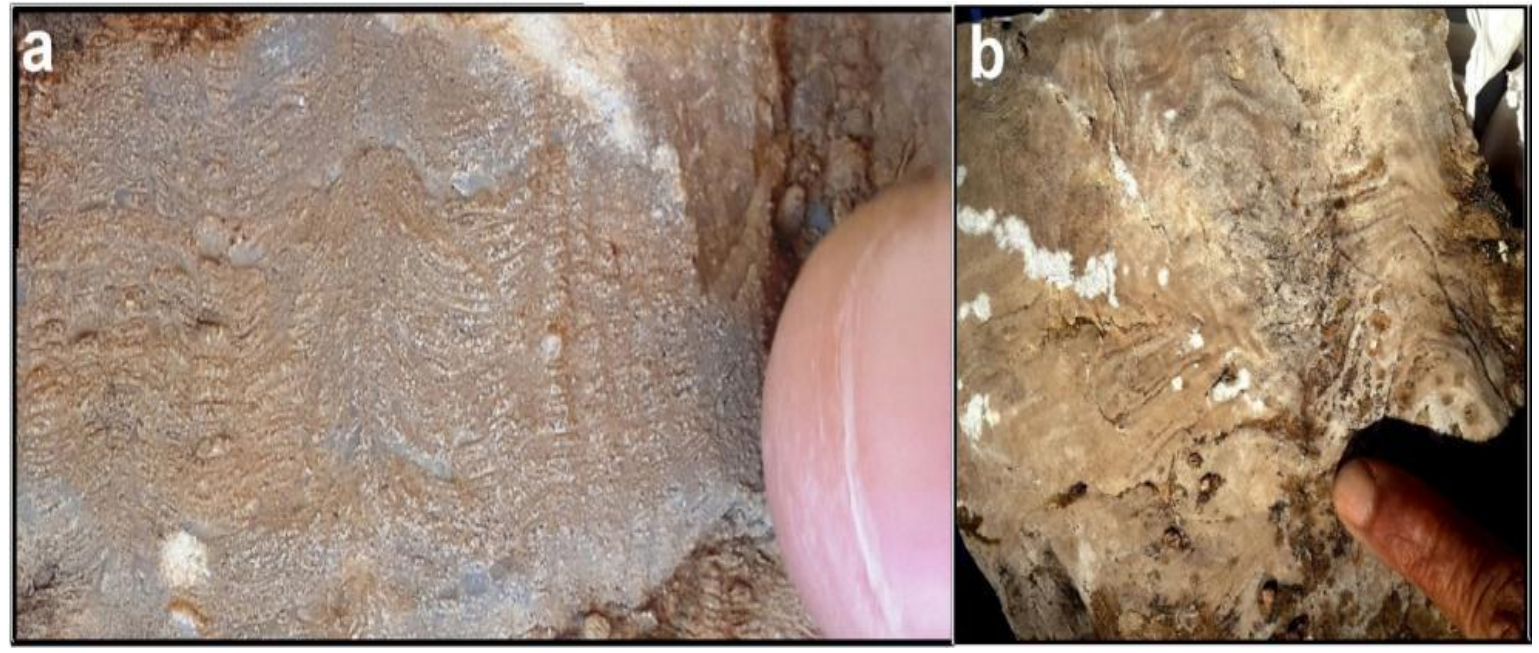

Fig. 16 a): Algal Stromatolitic Bindstone in the Barda Balaka Outcrops,

b):Stromatoporoid Bindstone in the Qzlja Outcrop, See Figure 17 for Enlarged Views.

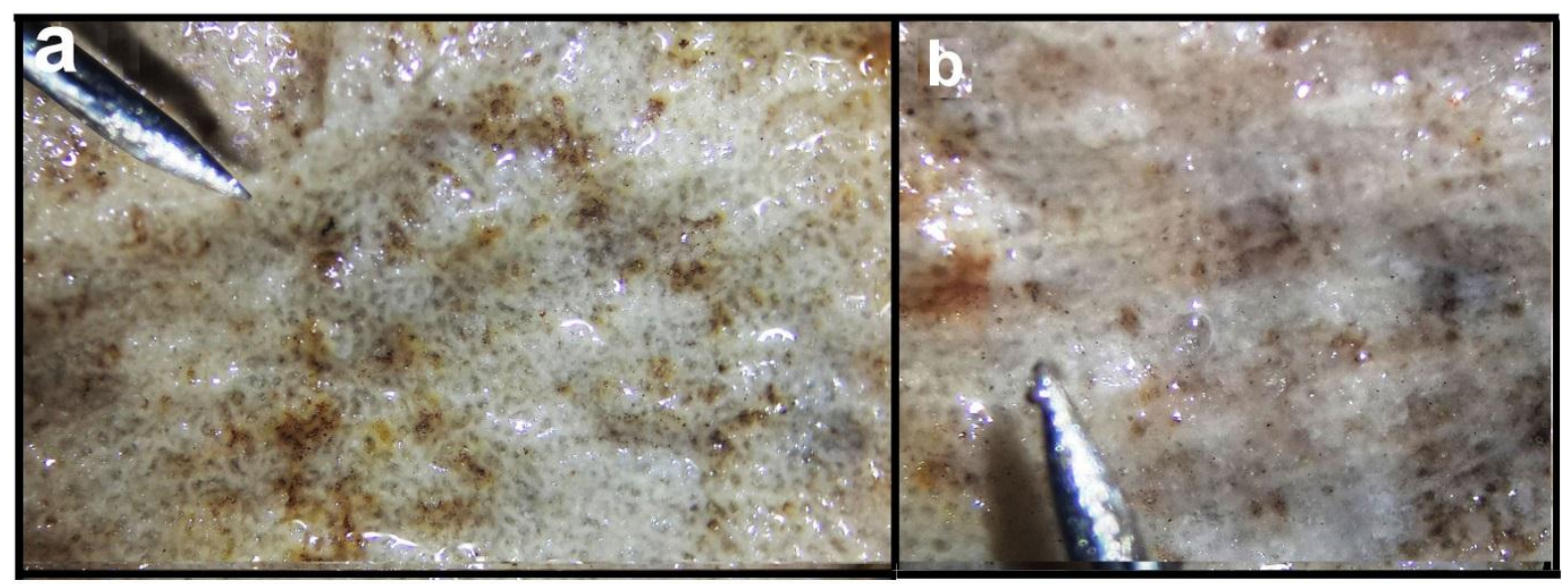

Fig. 17: Stromatoporoid (Sponge) Bindstone (or Framestone) Under Normal Light stereoscope microscope in the Qzlja outcrop, it was taken from the top of figure 16b. a Cross Section and b) Vertical (longitudinal) Section, the Scale: is the Tip of Paper Pin (Needle).

\section{6- Foraminifera and red algae bioclasts packstone-wackstone (F6)}

This facies is located in the middle of the formation; it alternates with coral bafflestone facies, and consists, in outcrop, of dark - grey massive to crudely laminated limestone. This limestone is characterized by the occurrence of various 
foraminiferas skeletons of in-situ species and in most cases; it is associated with bioclasts of red algae and pelecypods in addition to lithoclasts, but without planktonic forams. There are many species of forams in the Bahe outcrop such as Borelis melo melo and Borelis melo Curdica and unknown miliolids (Figs.18a and b). While those of Mila Kawa outcrop, include different reworked nummulites, lepidocyclina and rotalids species (Fig. 19).

The age of the in situ forams of the former section is Late Middle Miocene due to presence of Borelis melo curdica-Borelis melo melo with other miliolids forams, while the age of latter outcrop is not known because the fossils are reworked.

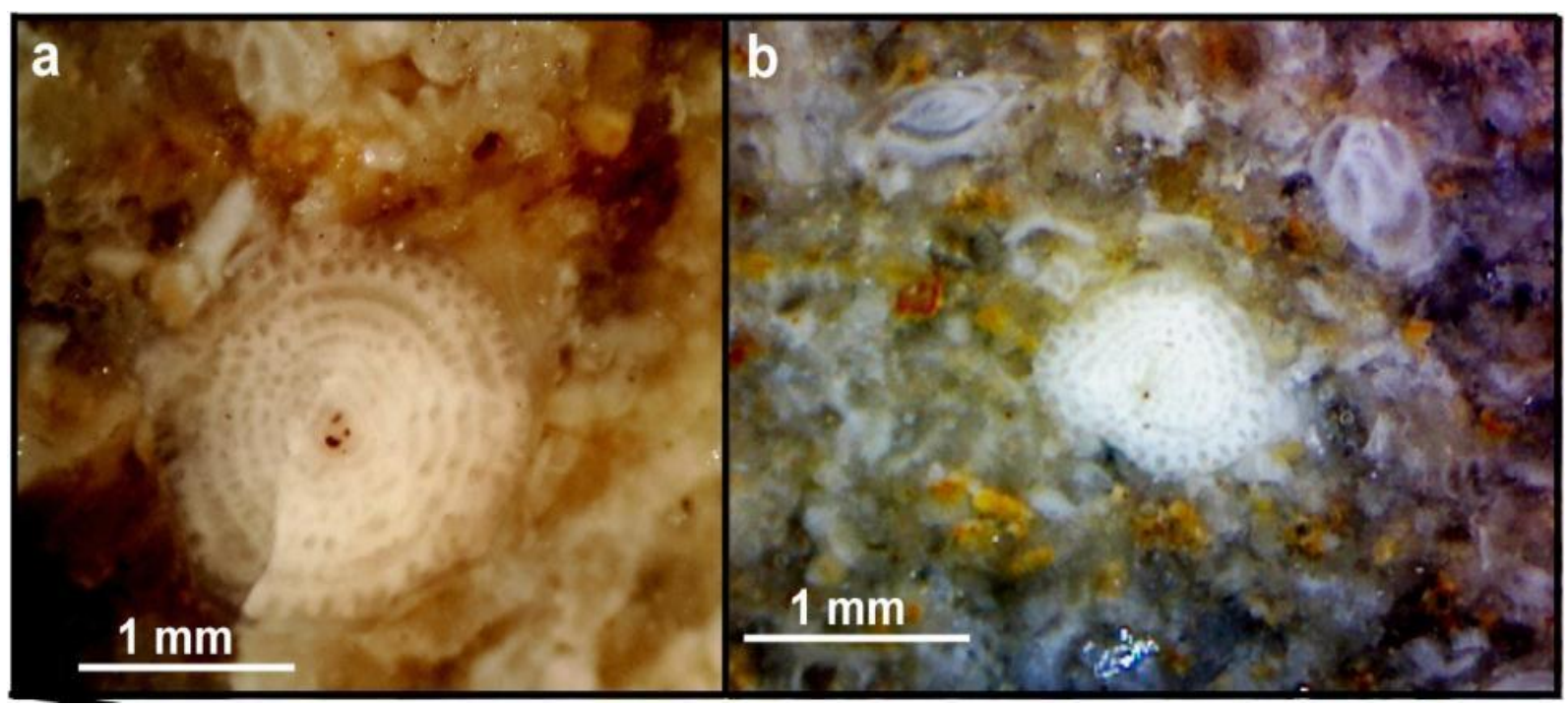

Fig. 18 a): Borelis melo curdica in the Qzlja-Bahe Outcrops, S. No.3., Under Stereoscopic Microscopy b): Foraminifera-Lithoclast Packstone with Borelis melo melo with other Miliolids foram S.No.10. Both Photos are Taken Under Normal Light by Stereoscope Microscope, S.No.4. 


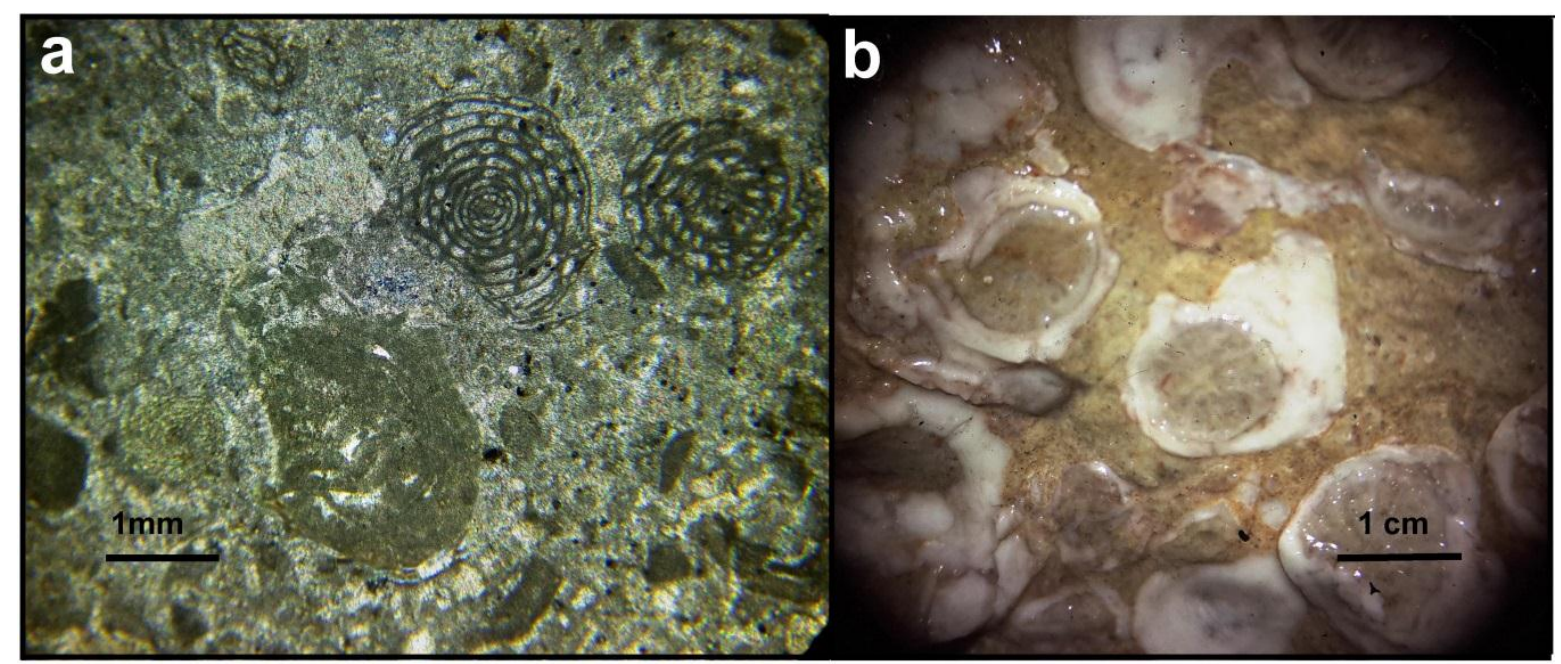

Fig. 19 a): Red algae (grey and black grains) and Foramioneral (Borelis melo curdica) Wackstone of the Bahe Outcrop.

b): Crustose red algae Covering Coral and Forming Massive Rocks in Lower Part of Qzlja Section, S.No.9.

\section{7- Reworked Foraminiferal-lithoclast grainstone-packstone (F7)}

The reworked forams are accompanied by terrigenous clasts of sedimentary, igneous and metamorphic rocks that are derived from nearby uplifted land. Additionally, they have intensively deformed both in brittle and ductile manners, which can be seen as suture contact between the forams and relatively deep penetration of one foram into others (Fig.20a and b). This deformation is tectonic and not lithostatics due to their location under the ophiolite sheets (Penjwin Ophiolite) and bounded below by the Merga Red Beds.

\section{8- Lithoclast grainstone (F8)}

The major components of this facies are lithoclasts, which consist of oval or spherical sand- sized grains of limestone. They consist of limestone clasts that are well sorted and well-rounded allochems bound together by spary calcite cement. They appear transparent under binocular microscope and in some intervals; this facies contains bioclasts (Fig.21a). The facies was deposited in high energy agitating environment in which all the fine grain sediments (lime mud) are washed out. Due to this washing, the space between the grains is remained empty and later during diagenesis filled with spary calcite cement. This facies is recorded in the Barda Balaka section only and alternates with lithoclast rudstone 
(limestone conglomerate),(Fig.21b) and coral bindstone. The age of this facies is not known and the present authors are not sure if it belongs to Govanda Formation because the rocks of this outcrop are mixed and brecciated, and the layer boundaries are not distinguishable between facies (beds).
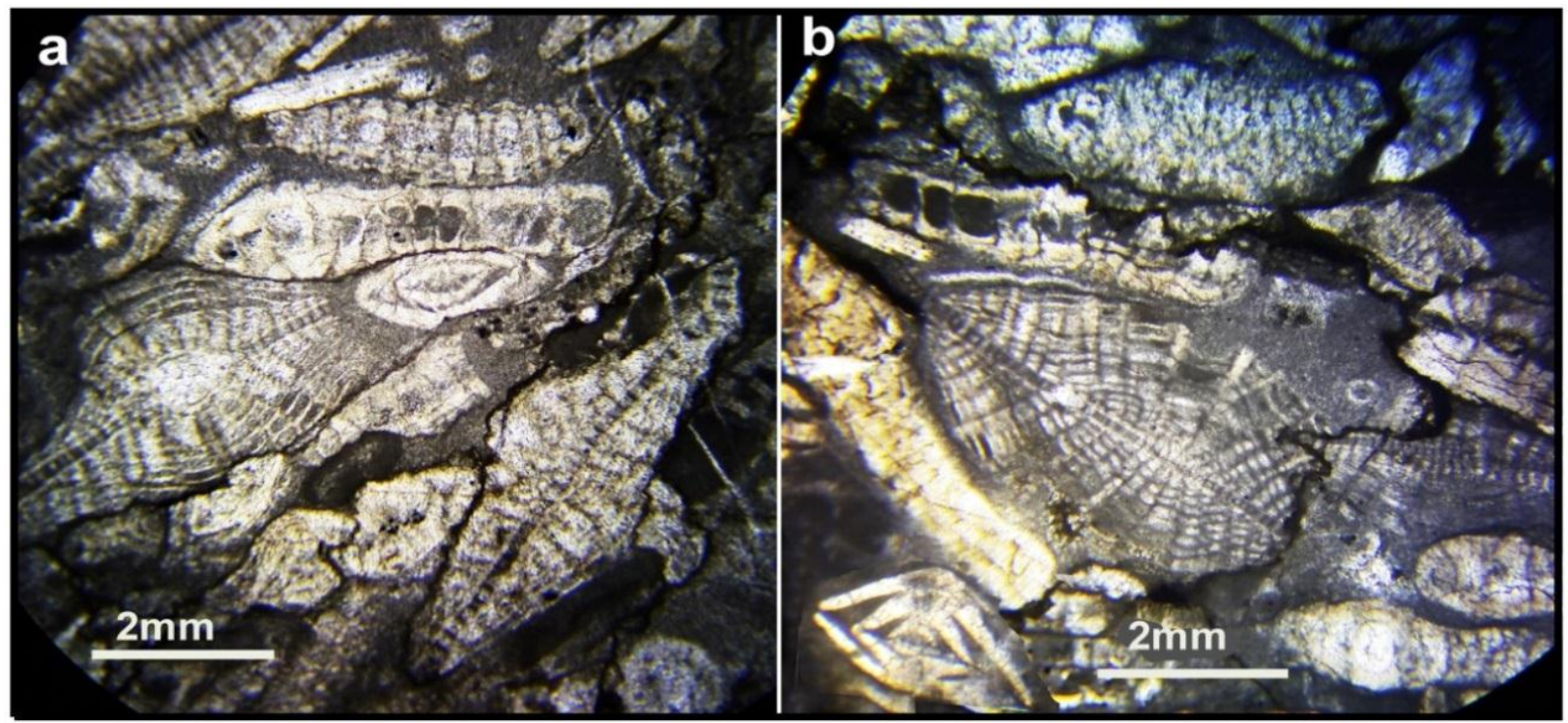

Fig. 20a and b: Reworked Foraminiferal Packstone from Mila Kawa Outcrop. The Forams are Intensively Deformed Both in Brittle and Ductile Situation so that Appear as Suture Contact Between the Forams and Relatively Deep Penetration of One Foram into Others. S.No.14, ppl., X40.

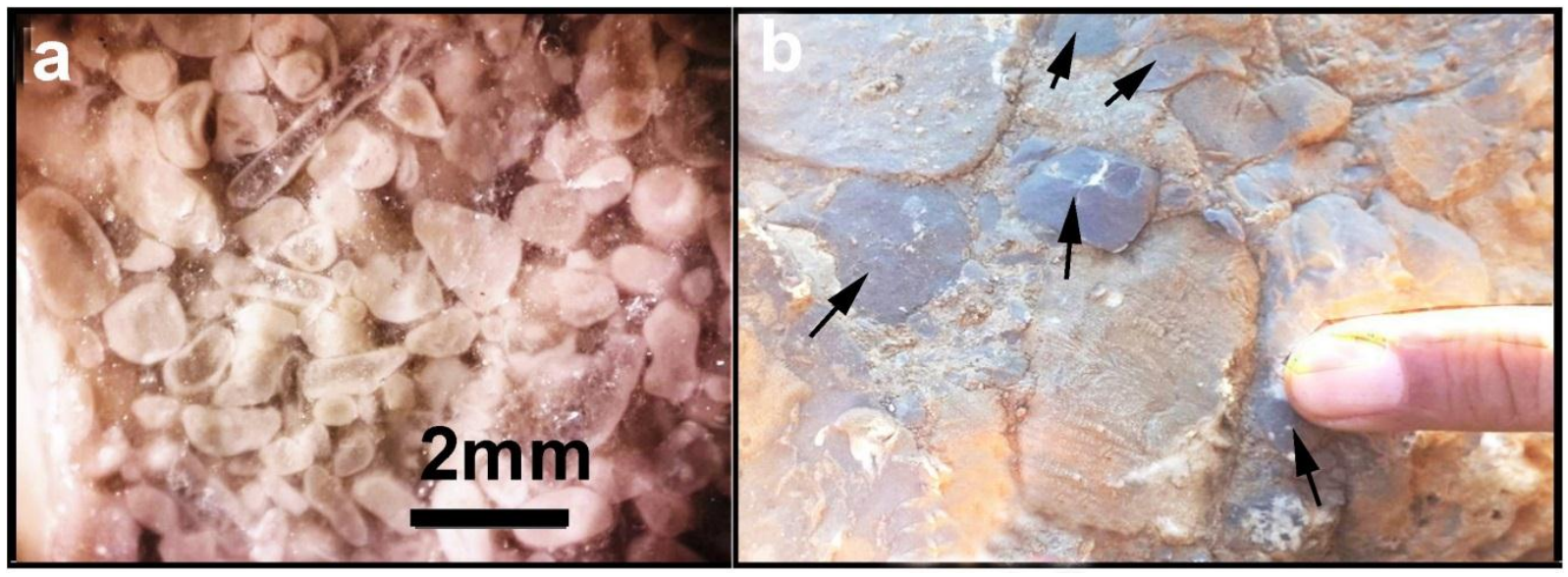

Fig. 21 a): lithoclast Grainstone in the Barda Balaka Outcrop, S.No.19a, Normal Light, X20.

b): Rudstone Consisting of Lithoclast (Black Grains Indicated by Arows) and Coral Bioclast (Light Grey), S.No.19b. 


\section{9- Terrigenous lime sandstone (F9)}

The name of this facies refers to its derivation from terrestrial (terrigenous) land by rivers and to its limestone clasts content. The major components of this facies are lithoclasts, which have angular, elongate and badly sorted coarse sand-sized grains of different rocks (Figs.23a and b). They consist of deformed fossils Nummulite whole skeletons and fragments (nu), fossil fragment, black limestone, chert, jasper metamorphic, volcanic and igneous (Figs.22 and 23) and clasts that were derived from terrestrial lands and they were surrounded basin of deposition.

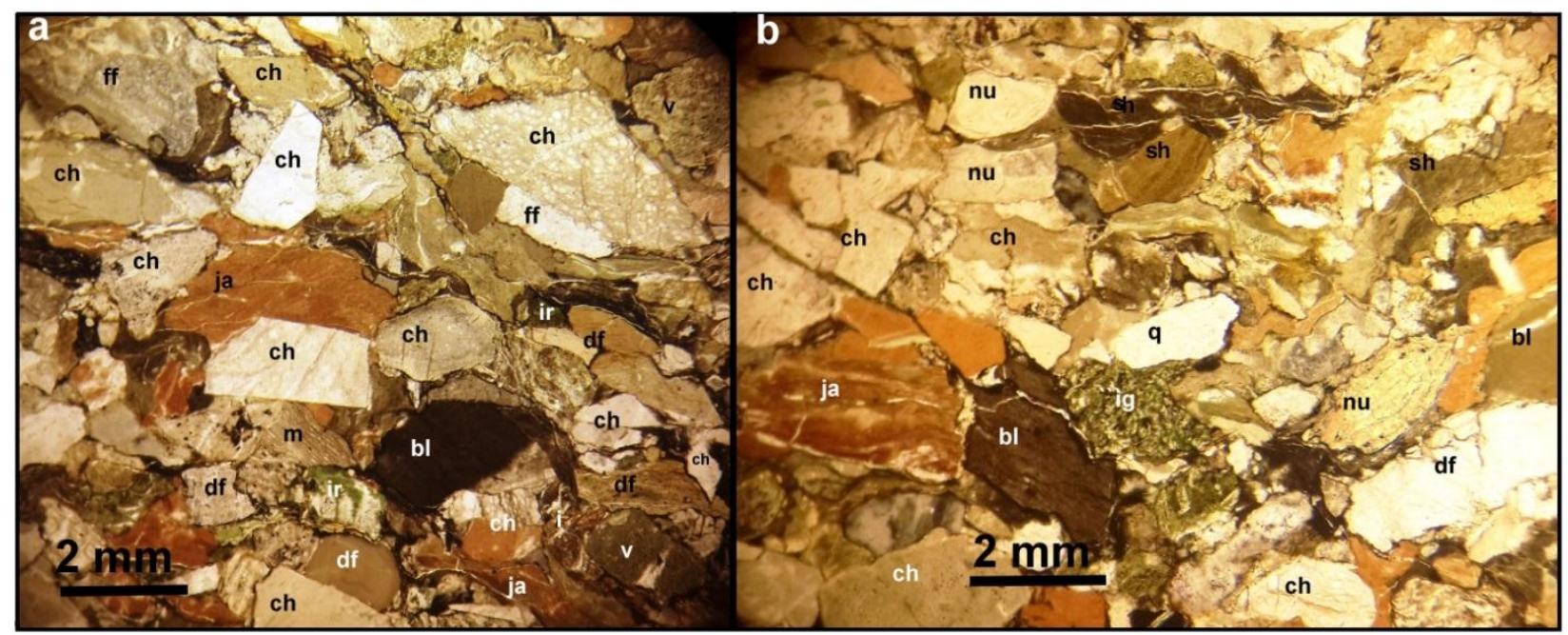

Fig. 22: The Terrigenous Sandstone Containing Lithoclasts and Deformed Fossils (df), Nummulite (nu), Fossil Fragment (ff), Black Limestone (bl), Chert (ch), Jasper (ja), Limestone (l) Metamorphic (m), Shale (sh) Volcanic (v) and Igneous (ir), Both Photos are Under Plane Polarized Light, S. No. 14. ppl, X40. 

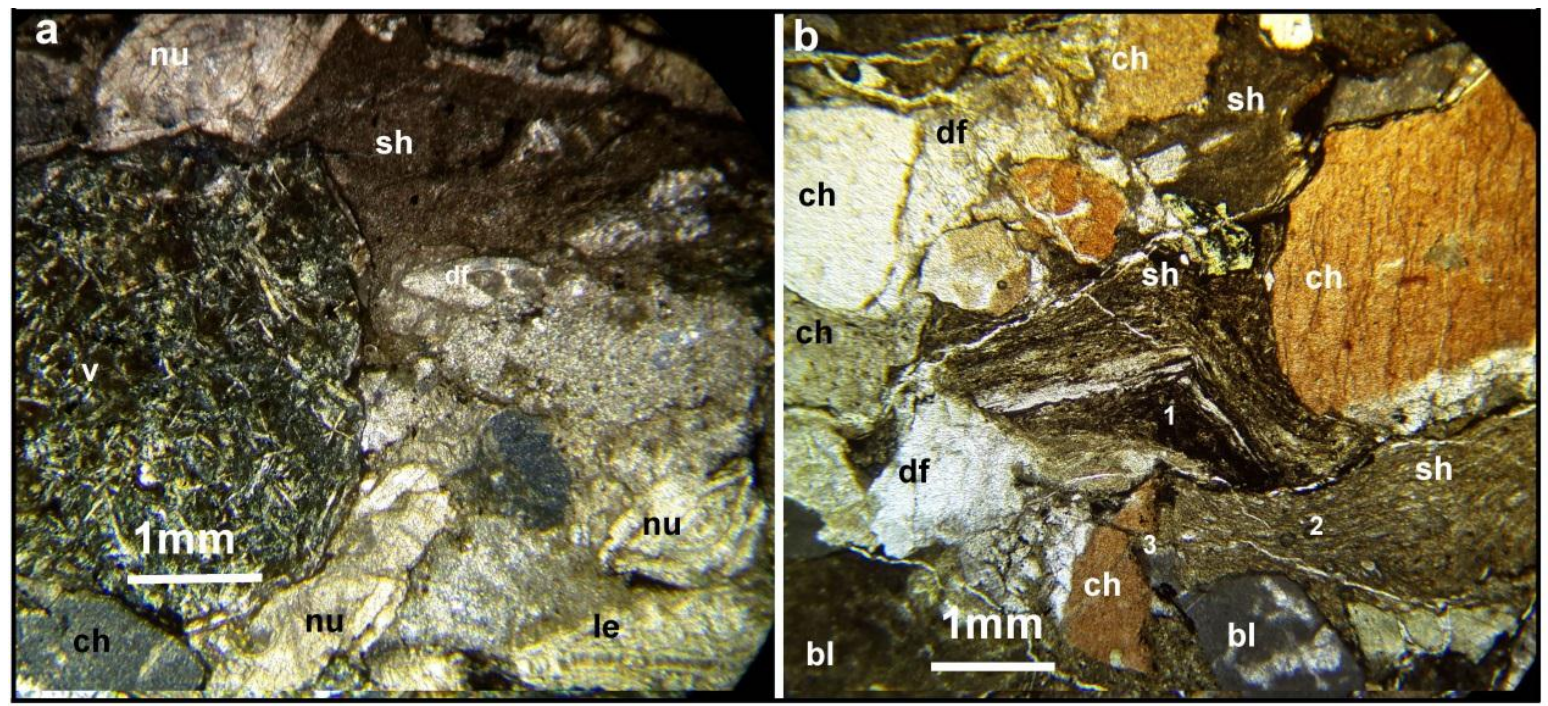

Fig. 23 a.): Association of Deformed Nummulite (df) and lepidocyclina (le) with Volcanic (v) and Chert Fragments (ch). b): Clear Flexure Slip and Flexure Flow Folding (1 and 2) and Faulting (3), Both Photos Belong to the Mila Kawa Section (or outcrop), S. No.15, ppl, X40.

This facies is directly located below the reworked- foraminiferal packstone in Mila Kawa outcrop. In few beds, sedimentary, igneous and metamorphic rocks clasts can be seen together. These clasts show clear syntectonics flexure-slip and flexureflow folding (1 and 2) and faulting (3) (Fig. 23b). The different types of clasts are indicative of diversity of sources from which the sediments derived, which included different type of sedimentary, igneous and metamorphic rocks. There are gradational facies that changes between this facies and the previous one (foraminifera and lithoclast packstone-wackstone). Figures (20a and b) show this gradation, which contains both nummulite (nu) and lepidocyclina (le) forams with clasts of different rocks (Fig. 23a).

\section{INTERPRETION AND DISCUSSION}

In the discussion of the Govanda Formation, one does not know when and where to start writing because of many factors and properties. Among these factors, the boundary condition of the formation, lithology, facies diversity, and its tectonic location in the area, which is highly variable. The most important issue of the boundary condition is its resting on the tilted and folded Qulqula Radiolarian Formation in a stratigraphic relation of angular unconformity (Fig. 6). In literature, this unconformity is not the only angular one in the Zagros Fold - Thrust Belt 
(Karim et al., 2011). Karim and Baziany (2007, p.58) concluded an angular unconformity between the Qulqula Radiolarian Formation and the Red bed Series in foothill of the Qandil and Gimo Mountain Ranges in Qaladiza and Mawat areas nearly on the southern boundary of the Sanandij-Sirjan Zone. They discussed that the age of tilting is pre-Paleocene age. The angularity of the present unconformity is better expressed in lateral continuity and the tilting angle between the two units that was represented by basal conglomerates (Fig.7).

Another issue is its location in the Suture (Sanandij-Sirjan) Zone and according to Ghazi and Moazzen (2015), it is the most active tectonic zone of Zagros since Jurassic. Moreover, Sadeghi and Yassaghi (2016) mentioned that this zone was an area of collision of Zagros. The original location of the Govanda Formation was more northeastward in the Zone but it had been moved (with all other rocks) southwestward by thrusting of the Iranian (Eurasian) plate over the Arabian one.

From description of the facies types, it is obvious that normal- marine and shallow carbonate rich fossils were deposited during the late Middle Miocene. The richness of the formation with fossils is most possibly attributed to rich nutrients that were arrived the basin from the surrounding sources areas. It is possible that each source was represented by a thrust sheet and the basin may be piggy back basin. The age, zone and angularity of deposition are very important for tectonic and paleogeographic evolution of the Zagros. Although, the carbonate deposition (with associated clastics) shows active tectonic, but not to a degree to justify a continental-continental colliding of the Arabian-Iranian plates as cited by Mouthereau et al. (2007), Allen and Armstrong (2008); Aral et al. (2010), McQuarrie and van Hinsbergen (2013); they concluded that it happened during the Miocene. This colliding does not match with the subsidence of the area and deposition of normalmarine carbonate during the Miocene as mentioned by Buday (1980); Jassim and Goff (2006) and it is inferred in this present study. Conversely, the studied area must be subsided to a basin not uplifted to a terrestrial area.

Therefore, the colliding must had occurred before the Miocene due to intense deformations in the pre-Miocene age as testified by angular unconformity with the Qulqula Radiolarian Formation (Figs.6 and 9). It seems that the studied area was an intercontinental shallow basin. It is more or less similar to the present day eastern Mediterranean Sea or Arabian Gulf in which shallow water carbonates and clastics deposit. The Paleogeographic map of Scotese (2001) during the Middle Miocene shows that this basin was connected to open marine via Mediterranean, Arabian Seas and Arabian Gulf (Fig. 24). Other evidence for connection is the map published by 
Rögl and Steininger, 1983 in Çağatay et al. (2006), it shows the latter sea that extend to the near studied area during Middle Miocene. Additionally, when the map of the Bosworth et al. (2005) is considered, there is a connection to the Arabian Gulf and Indian Ocean. The richness of the Govanda Formation with normal marine fauna strongly aids the connection of the studied area to the above-mentioned seas and ocean.

Last issue of the Formation is its environment, which was normal- marineshallow water sea as indicated by its richness in fossil content. This environment can be subdivided into several ones according to the specific depositional facies. The content of echinoderm and coral floatstone and rudstone are indicative of fore-reef. While the coral framestone and bufflestone with different algae represent reefal core environment. The foraminiferas and red algae bioclasts, packstone-wackstone with miliolid forams and stromatolies are best evidence for back-reef environment.

The existed lagoon environment was of semi-restricted lagoons, which is called "leaky lagoon" by Kjerfve (1994), who defined it as a lagoon connected through wide channels to sea by which the water interchange is fast and unlimited. Lower, middle and upper parts of the formation were deposited in the fore-reef, reef and back-reef respectively.

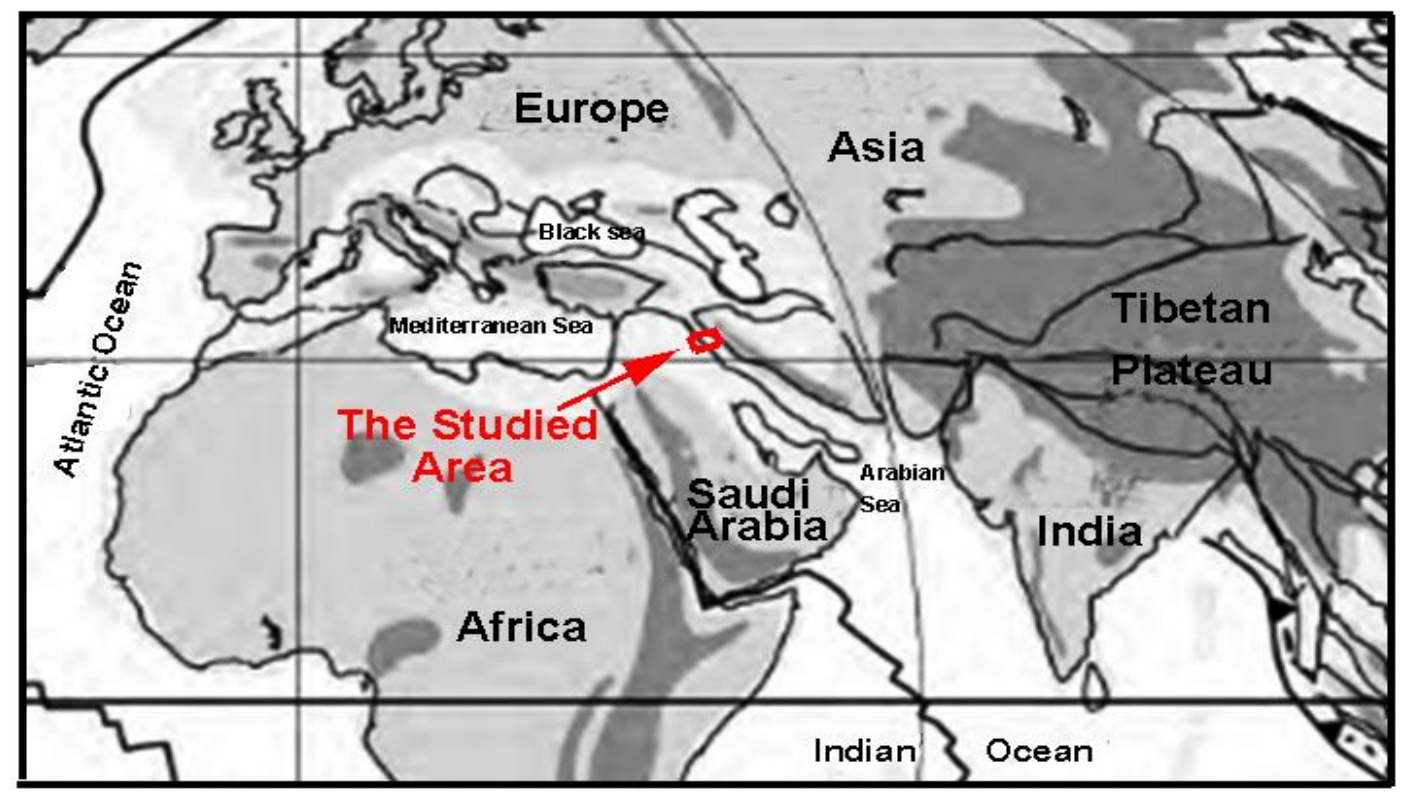

Fig. 24 Paleogeographic Mmap of Middle East During Middle Miocene Showing the Connection of the Studied Area to Arabian Gulf, Mediterranean and Arabian Sea (Scotese, 2001). 


\section{CONCLUSION}

1- The upper boundary of the Govanda Formation is erosional (not exist) while the lower contact is tectonic, it rested on the Qulqula Radiolarian Formation in an angular unconformity relationship and rested on the Red Bed Series in Rashan Section.

2- The main facies of the formation are pelecypod floatstone Facies, coral and lithoclast rudstone, coral bufflestone, stromatolitic bindstone, foraminifera and red algal bioclasts, packstone-wackstone, reworked foramioneral-lithoclast grainstone-packstone, lithoclast grainstone and terrigenous lime sandstone.

3- Detailed Facies analysis indicates that the formation was deposited in a highenergy shallow, normal marine of fore-reef, reef and back-reef environments.

4- The Sanandij-Sirjan Zone was subjected to extension not compression (continentalcontinental collision) as cited in some studies.

5- The richness of the basin with fauna indicates that the formation was connected to normal marine of both Indian Ocean and Mediterranean Sea.

\section{REFERENCES}

Al-Barzinjy, S.T.M., 2005. Stratigraphy and Basin Analysis of Red Bed Series from Northeastern Iraq, Kurdistan Region. Unpublished Ph.D. Thesis, University of Sulaimani, $159 \mathrm{p}$.

Al-Hietee, S.A.A., 2012. Facies Architecture and Sequence Stratigraphy of the Lower and Middle Miocene, Kirkuk area, North Iraq. MSc Thesis, College of Science, University of Baghdad, $97 \mathrm{p}$.

Allen, M. B., and Armstrong, H. A., 2008. Arabia-Eurasia Collision band the Forcing of Mid-Cenozoic Global Cooling. Palaeogeogr. Palaeocl., Vol. 265, pp. 52 - 58.

Aral I. O., Zattin M., and Cavazza W., 2010. Apatite fission-track data for the Miocene Arabia-Eurasia collision Geology, Vol. 38, No. 1, pp. 35 - 38.

Baziany M. M., 2013. Depositional Systems and Sedimentary Basin Analysis of the Qulqula Radiolarian Formation of the Zagros Suture Zone, Sulaimani Area, Iraqi Kurdistan Region. PhD Thesis, College of Science, University of Sulaimani, $200 \mathrm{p}$.

Bellen R. C., Dunnington H. V., Wetzel R. and Morton D. 1959. Lexique Stratigraphique, International. Asia, Iraq, Vol. 3c. 10a, 333 p.

Bosworth W., Huchon P., and McClay, K., 2005.The Red Sea and Gulf of Aden Basins, Journal of African Earth Sciences 43: 334 - 378.

Buday T., 1980. Regional Geology of Iraq, vol. 1, Stratigraphy, Edited by Kassab IM, Jassim SZ, GEOSURV. Baghdad, 432 p. 
Buday T., Jassim S.Z.,(1987). The regional geology of Iraq, Vol. 2: Tectonism, Magmatism, and Metamorphism, edited by Abbas M. J., Jassim S. Z., GEOSURV, Baghdad, 352 p.

Çağatay M. N., Görür N., Flecker R., Sakınç M., Tünoğlu C., Ellam R., Krijgsman W., Vincent S., Dikbaş A., 2006. Paratethyan-Mediterranean Connectivity in the Sea of Marmara region (NW Turkey) during the Messinian, Sedimentary Geology 188: 171 - 187.

Dunham R. J., 1962. Classification of Carbonate Rocks According to Depositional Texture: in Northern Iraq. Arabian Gulf, Geology and Productivity. AAPG, Foreign Reprint Series, No.2.

Embry A. F., and Klovan J. E., 1971. A late Devonian Reef Tract on North-Eastern Banks Island, N.W.T.: Bulletin of Canadian Petroleum Geology, Vol. 19, pp. $730-781$.

Flugel E., 2004. Microfacies Aanalysis of Limestones, Springer Verlag, Berline, $976 \mathrm{p}$.

Ghazi J. M., and Moazzen M., 2015. Geodynamic Evolution of the Sanandij-Sirjan Zone, Zagros Orogen, Iran, Turkish J Earth Sci., Vol. 24, pp. 513 - 528.

Jamshidi B. M., Masoudi F., Collins A.S., and Cox G. , 2010. Dating of Precambrian Metasedimentary Rocks and Timing of their Metamorphism in the Soursat Metamorphic Using - LA-ICP-MS_U Pb_Dating_of_Zircon_and_Monazite Complex, NW-Iran, Journal of Sciences, University of Tehran, Islamic Republic of Iran, No. 21, Vol. 4, pp. 311 - 319.

Jassim S. Z., and Goff J. C., 2006. Geology of Iraq. Published by Dolin, Prague and Moravian.

Karim K. H., Koyi, H., Baziany M. M., and Hessami, K., 2011. Significance of Angular Unconformities Between Cretaceous and Tertiary Strata in the North Western Segment of the Zagros Fold-Thrust Belt, Kurdistan Region, NEIraq. Geological Magazine, Cambridge University Press, No. 148, Vol. 5 - 6, pp. 925 - 939.

Karim K.H., Hama N. R., and A-Bidary M., 2016. Paragenesis of Asnawa Iron Ore in Penjween Area, Zagros Suture Zone Kurdistan Region, North-eastern Iraq" accepted for publication by Iranian Journal of Earth Science Azadi University, Mashhad, Iran.

Karim K. H., 2007. Lithology of Avroman Formation (Triassic) Northeast Iraq. Iraqi journal of earth Science, No. 7, Vol. 1, pp. 1 - 12. 
Karim K. H., and Baziany M. M., 2007. Relationship between Qulqula Conglomerate Formation and Red Bed Series at Qulqula area, NE-Iraq, Iraqi journal of Earth science, Mosul university, No. 7, Vol. 1, pp.1 - 12.

Karim K. H., Habid H. R., and Raza S. M., 2009. Lithology of the Lower Part of Qulqula Radiolarian Formation Kurdistan Region, NE-Iraq. Iraqi Bulletin of Geology and Mining, No, 5, Vol. 1, pp. 9 - 23.

Kjerfve B., 1994. Coastal Lagoons, in Coastal Lagoon Processes. B. Kjerfve (ed.). Elsevier Oceanography Series, Vol. 60, pp. 1 - 8.

McCook L. J., Jompa J., and Diaz-Pulido G., 2001. Competition Between Corals and Algae on Coral Reefs: a Review of Evidence and Mechanisms. Coral Reefs. No. 19, Vol. 4, pp. 400 - 417.

McConnell R. L., 1975. Biostratigraphy and Depositional Environment of Algal Stromatolites from the Mescal Limestone (Proterozoic) of Central Arizona Precambrian Research, No. 2, Vol. 3, pp. 317 - 328.

McQuarrie N., and van Hinsbergen D. J. J., 2013. Retro-Deforming the Arabia-

Eurasia Collision Zone: Age of Collision Versus Magnitude of Continental Subduction, Geology, Vol. 41, pp. $315-318$.

Melim L. A., and Scholle P.A., 1995. The Forereef Facies of the Permian Capitan Formation: The role of Sediment Supply Versus Sea Level Changes. J. Sed. Res. Vol. 65, No. 1, pp. 107 - 118.

Moghadam H. S., and Stern R. J., 2015. Ophiolites of Iran: Keys to Understanding the Tectonic Evolution of SW Asia: (II) Mesozoic Ophiolites, Journal of Asian Earth Sciences 100: pp. 31 - 59.

Mouthereau F., Tensi J., Bellahsen N., Lacombe O., De Boisgrollier T., and Kargar S., 2007. Tertiary Sequence of Deformation in a Thin-Skinned/Thick-Skinned Collision Belt: the Zagros Folded Belt (Fars, Iran), Tectonics, 26, TC5006.

Pomar L., Gili E., Obrador A. and Ward W.C., 2005. Facies Architecture and HighRresolution Sequence Stratigraphy of an Upper Cretaceous Platform Margin Succession, Southern Central Pyrenees, Spin. In Sedimentary Geology175, 2005, Sedimentology In: The 21st Century, pp. 338 - 365.

Praptisih S., and Kamton M. S., 2014. Carbonate Facies and Sedimentation of the Klapanunggal Formation in Cibinong, West Java Indonesian Journal of Geoscience, Vol. 3, pp. 175 - 183. 
Riding R., and Tomas S., 2006. Stromatolite Reef Crusts, Early Cretaceous, Spain: Bacterial Origin of in Situ-Precipitated Peloid Microspar. Sedimentology, Vol. 53, pp. 23 - 34.

Sadeghi S., and Yassaghi A., 2016. Spatial Evolution of Zagros Collision Zone in Kurdistan, NW Iran: Constraints on Arabia-Eurasia Oblique Convergence, Solid Earth, Vol. 7, pp. 659 - 672.

Scholle P. A., and Ulmer-Scholle D. S., 2006. Color Guide to Petrography of Carbonate Rocks AAPG Memoir 77, Publisher: AAPG, 474p.

Scote C. R., 2001. Atlas of Earth History, Volume 1, Paleogegraphy, PALEO MAP, Arlington, Texas, 52p.

Yousefirad M. 2011.Genetic Relation of the Zagros Thrust and Sanandaj-Sirjan Zone. Journal of American Science, Vol. 7, No. 7, pp. 835 - 841.

Walker R. G., and James N. P. 1992. Facies Models Response to Sea Level Change. Geo Text, Geological Association of Canada, 454 p.

Wilson J. L., 1975. Carbonate Facies in Geologic History. Spriger -Verlag, Berlin Heidelbreg, $471 \mathrm{p}$.

Wu L., Jiao Y., and Rong H., 2012 .Reef Types and Sedimentation Characteristics of Changing Formation in Manyue - Honghua Section of Kaixian, Northeastern Sichuan Basin Journal of Earth Science, Vol. 23, No. 4, pp. 490 - 505. 